\title{
An Overview of the Geochemical Characteristics of Oceanic Carbonatites: New Insights from Fuerteventura Carbonatites (Canary Islands)
}

\author{
Gabriele Carnevale $^{1, *(\mathbb{D})}$, Antonio Caracausi ${ }^{2}$, Alessandra Correale ${ }^{2}$, Laura Italiano ${ }^{1}$ (D) and Silvio G. Rotolo ${ }^{1,2}$ \\ 1 Dipartimento di Scienze della Terra e del Mare (DiSTeM), Università degli Studi di Palermo, \\ 90133 Palermo, Italy; laura.italiano@community.unipa.it (L.I.); silvio.rotolo@unipa.it (S.G.R.) \\ 2 Istituto Nazionale di Geofisica e Vulcanologia (INGV), 90146 Palermo, Italy; antonio.caracausi@ingv.it (A.C.); \\ alessandra.correale@ingv.it (A.C.) \\ * Correspondence: gabriele.carnevale@unipa.it; Tel.: +39-392-161-7712
}

Citation: Carnevale, G.; Caracausi,

A.; Correale, A.; Italiano, L.; Rotolo,

S.G. An Overview of the Geochemical

Characteristics of Oceanic

Carbonatites: New Insights from

Fuerteventura Carbonatites (Canary

Islands). Minerals 2021, 11, 203.

https://doi.org/10.3390/min11020203

Academic Editor: Aleksey Sadekov

Received: 18 December 2020

Accepted: 12 February 2021

Published: 15 February 2021

Publisher's Note: MDPI stays neutral with regard to jurisdictional claims in published maps and institutional affiliations.

Copyright: (c) 2021 by the authors. Licensee MDPI, Basel, Switzerland. This article is an open access article distributed under the terms and conditions of the Creative Commons Attribution (CC BY) license (https:// creativecommons.org/licenses/by/ $4.0 /)$.

\begin{abstract}
The occurrence of carbonatites in oceanic settings is very rare if compared with their continental counterpart, having been reported only in Cape Verde and Canary Islands. This paper provides an overview of the main geochemical characteristics of oceanic carbonatites, around which many debates still exist regarding their petrogenesis. We present new data on trace elements in minerals and whole-rock, together with the first noble gases isotopic study ( $\mathrm{He}, \mathrm{Ne}, \mathrm{Ar}$ ) in apatite, calcite, and clinopyroxene from Fuerteventura carbonatites (Canary Islands). Trace elements show a similar trend as Cape Verde carbonatites, almost tracing the same patterns on multi-element and REE abundance diagrams. ${ }^{3} \mathrm{He} /{ }^{4} \mathrm{He}$ isotopic ratios of Fuerteventura carbonatites reflect a shallow (sub-continental lithospheric mantle, SCLM) He signature in their petrogenesis, and they clearly differ from Cape Verde carbonatites, i.e., fluids from a deep and low degassed mantle with a primitive plume-derived He signature are involved in their petrogenesis.
\end{abstract}

Keywords: trace elements; noble gases isotopes; oceanic carbonatites; Fuerteventura; Cape Verde

\section{Introduction}

Carbonatites are rare carbonate-rich rocks of igneous origin, with more than 50\% modal carbonates [1]. Alkaline-carbonatite complexes are considered one of the main sources of critical metals for key economic sectors in heavily industrialized countries, and their occurrence is almost exclusive in continental regions [2], while in oceanic settings, carbonatites (we refer to carbonatite complexes, occurring beside carbonatite micro-enclaves or veins in mantle xenoliths) are very rare and they are limited to only two occurrences on the western side of the Atlantic Ocean just in front of the African coasts: at Cape Verde Archipelago and Fuerteventura Island (Canary Archipelago).

Carbonatite petrogenesis is still a debated topic, and three petrogenetic processes have been variably proposed, all being related to the formation of a primary carbonate melt derived from a carbonated mantle [3]: (1) low-degree partial melting of a carbonated mantle source [4-6]; (2) immiscible separation from a $\mathrm{CO}_{2}$-rich alkaline silicate melt [7,8], and (3) the late-stage result of a fractional crystallization of a carbonated alkaline silicate melt $[6,9,10]$. Another important petrogenetic process is the (4) assimilation of carbonates in relatively shallow magma chambers (e.g., [11]).

The nature of the mantle that sourced the oceanic carbonatites (shallow convective mantle vs. a deep-seated mantle reservoir, plume-type) is still a debated issue. A shallow origin for oceanic carbonatites was suggested for some oceanic carbonatites [12], with the plume contribution limited to a thermal input, a trigger for low-degree partial melting at the base of the oceanic lithosphere. Another trigger possibility is the "metasomatic underplating" hypothesis, where crustal fractures that developed during hot-spot magma ascent 
allow seawater to infiltrate and to serpentinize the sub-Moho mantle, with Ca-rich hydrothermal fluids [13]. A thickened and metasomatized oceanic lithosphere is needed [14], and a relatively hot environment could favour both the survival of carbonate melt at shallow mantle depths and the emplacement of carbonatites at or near the surface [15], at the same time becoming more calcic with respect to primary dolomitic melts $[15,16]$. In addition, the role of the carbonated eclogite for deep global cycling of carbon and the potential source for carbonatites is also recognized [17-19]. Other models proposed for the petrogenesis of oceanic carbonatites involve (i) the contribution of marine carbonates recycled via subduction, (ii) carbonates assimilated in shallow magma chambers $[11,12,14,20]$, or (iii) the involvement of primordial deep-mantle carbon [21-23].

An increasing number of multi-isotopic studies (C-O-Sr-Nd-Pb) tackled the petrogenesis of oceanic carbonatites and the characterization of their mantle source [12,14,20-22,24,25], and more recently, additional constraints were placed by noble gas isotopes [23]. Indeed, their properties (such as a large mass range, high volatility, and chemical inertia) make noble gas geochemical tracers of primary importance [26-28] to investigate mantle heterogeneity and degassing and mantle-crust interaction processes occurring in the volcanic plumbing systems (e.g., crustal assimilation). Despite their important role and potential significance for deciphering carbonatite genesis, there are no previous studies of noble gas isotopes in Fuerteventura carbonatites. On the contrary, noble gas isotopes in Cape Verde carbonatites are widely studied [23], also because carbonatite outcrops are present in at least six of the ten Cape Verde Islands (S. Vicente, S. Nicolau, Maio, Santiago, Fogo, and Brava), while on Canary Islands, carbonatites occur only on Fuerteventura (the easternmost island of the Canary Archipelago). Mata et al. (2010) [23] recognized the presence of fluids from a deep and low degassed mantle (He isotopic ratios higher than the typical mid-ocean ridge basalt MORB mantle values of $8 \pm 1 \mathrm{Ra}$ ) in Cape Verde carbonatites, supporting a deep-rooted mantle plume in the region as inferred by geophysical investigations [29,30]. However, this is not necessarily so as the helium mantle signature can easily survive during the contribution of hydrothermal fluids that can introduce surface-related noble gases, nitrogen, and $\mathrm{CO}_{2}$. This evidence supports the presence of non-recycled carbon in the genesis of the Cape Verde carbonatites.

The aim of this paper is firstly to summarize the geological, petrological, and geochemical background of the two oceanic carbonatite complexes (Fuerteventura and Cape Verde) in order to discuss analogies and differences. We also integrate the literature data (trace elements and C-O-Sr-Nd-Pb-He-Ne-Ar isotopes) with new geochemical data from Fuerteventura, which include major and trace element determinations on whole-rock samples and minerals and also the first noble gas $(\mathrm{He}, \mathrm{Ne}, \mathrm{Ar})$ isotopic analysis of Fuerteventura carbonatites. Data are discussed together in order to add some new constraints on the origin of Fuerteventura carbonatites and further characterize their mantle source. We also briefly discuss the possible future research directions to better address the petrogenesis of carbonatites in such rare and particular geodynamic settings.

\section{Geological and Geochemical Background}

\subsection{Regional Geology}

\subsubsection{Fuerteventura (Canary Islands)}

The volcanism of the Canary Archipelago is located $100 \mathrm{~km}$ off the northwestern African continental margin (Figure 1a). The age of the oceanic crust beneath the Canary Islands is constrained by the $175 \mathrm{Ma}$ S1 magnetic anomaly separating the easternmost Canary Islands and northwestern Africa and the 156 Ma M25 magnetic anomaly separating the westernmost islands of La Palma and Hierro [31-34]. The Moho depth decreases from west to east (i.e., towards Africa), varying in depth from approximately $12 \mathrm{~km}$ beneath El Hierro and La Palma to 20-30 km beneath Lanzarote and Fuerteventura [35]. Therefore, Fuerteventura is located on a transitional oceanic to continental crust.

Among all the Canary Islands, Fuerteventura is one of the few islands (together with La Palma) where the various phases of submarine formation, transitional phases, and 
subaerial growth are better recognized [36-45]. This volcanic island consists essentially of Mesozoic sediments, Oligocene submarine volcanic complexes, Late Oligocene transitional volcanic complexes, Miocene subaerial basaltic and trachytic lava flows, ultramafic, mafic to felsic intrusive rocks, and carbonatitic dyke swarms [40,45,46]. These intrusive and carbonatitic dyke swarms, with the submarine, transitional, and earliest subaerial complexes and their associated plutonic bodies, form a lithostratigraphic unit known as the Basal Complex.

Carbonatites and closely associated alkaline-rich-silica undersaturated rocks (clinopyroxenites, melteijites-ijolites, nepheline-sienites, and sienites) form a typical alkalinecarbonatitic association, outcropping in the central western part of the island, in an almost continuous NE-SW direction parallel to the coast. This association represents the first Magmatic Episode during upper Oligocene ( $\approx 25 \mathrm{Ma}$ ) [43], subsequent to the Submarine and early Transitional Volcanic Episodes. The main exposures of the alkaline-carbonatitic association are the northwestern Montaña Blanca-Esquinzo sector and the central-western Ajuy-Solapa sector (Figure 1b). The Early Miocene intrusion of a gabbroid-pyroxenitic series (Pájara Pluton), after the emplacement of the alkaline-carbonatitic complex, produced bands of thermal metamorphism on host rocks with up to $1 \mathrm{~km}$ of lateral extension [47]; thus, the original igneous mineral assemblage within the contact zone was variably overprinted and substituted with a metamorphic association composed of wollastonite, monticellite, diopside, vesuvianite, garnet, calcite, perovskite, alabandite, pyrrhotite, and $\mathrm{Nb}-\mathrm{Zr}$-Ca silicates (e.g., cuspidine-niocalite-baghdadite series) [48]. Nevertheless, carbonatite outcrops in Punta de La Nao (Ajuy-Solapa sector) escaped this thermal overprint and preserved their original igneous assemblage and textures [49]. Accordingly, in order to focus the study on well-preserved carbonatite rocks, all samples studied here were collected from Punta de La Nao area (Figure 1b).

After the Miocene subaerial volcanic activity, a period of quiescence occurred until the Pliocene, where renewed volcanic activity produced some basaltic volcanoes on the northern part of the island [39]. During the Plio-Quaternary, alluvial and aeolian complexes were also generated [50].

\subsubsection{Cape Verde Archipelago}

The Cape Verde Archipelago is located $500 \mathrm{~km}$ off the Senegalese coast (Figure 1a). The lithospheric crust beneath the islands is constrained by 140 Ma M16 and $120 \mathrm{Ma}$ M0 magnetic anomalies [51]. In the same way as the Canary Archipelago, the crustal thickness beneath the Cape Verde Islands is also anomalously high (up to $22 \mathrm{~km}$ ), and this is mainly due to magmatic transfer from the upper mantle to shallow (i.e., crustal) accumulation levels [52], although between the islands of the archipelago the crustal thickness decreases considerably to ca. $7 \mathrm{~km}$ [53]. Plume activity beneath the Cape Verde Archipelago is supported by tomographic studies, which show the evidence of a P-wave negative anomaly down to about $1000 \mathrm{~km}$, which includes the Azores and Canary plumes apparently reaching the core-mantle boundary [29].

The archipelago is composed of ten major islands, which can be divided into two groups: (i) northern Islands (S. Antão, S. Vicente, S. Luzia, S. Nicolau, Sal and Boavista) and (ii) southern Islands (Brava, Fogo, Santiago, and Maio).

The lack of a simple age progression of volcanism for the Cape Verde Archipelago indicates that the archipelago is located close to the rotation pole of the slowly drifting African Plate [54]. The oldest exposed magmatic rocks related to Cape Verde hot-spot volcanism occur on Sal Island, which preserves a magmatic history ranging from $25.6 \mathrm{Ma}$ to $0.6 \mathrm{Ma}$ [55], although a ${ }^{40} \mathrm{Ar}^{-39} \mathrm{Ar}$ study limits the volcanic evolution for Sal Island from around $15 \mathrm{Ma}$ to 1.1 Ma [54]. Indeed, several age determination studies on the Cape Verde Islands suggest that most of the volcanic activity took place from $16 \mathrm{Ma}$ until the present [54,56-59], such as the volcanic activity on S. Vicente (6.6 Ma to $0.3 \mathrm{Ma}$ ), on S. Antão (7.5 Ma to $0.1 \mathrm{Ma}$ ), on Maio (12 Ma-7 Ma) or on Fogo (Quaternary to the present). Currently, at least three islands of the Cape Verde Archipelago are considered volcanically active 
(S. Antão, Brava, and Fogo), with the latest historical eruptions on Fogo Island, i.e., the 1995 and 2014 events [60].

Cape Verde magmatism is strongly alkaline, as testified by the occurrence of nephelinitic and melilititic rocks in several islands, and all volcanic rocks are silica-undersaturated, with basanites, tephrites, and nephelinites representing the most dominant compositions [61,62]. Carbonatites occur on six out of ten islands (S. Vicente, S. Nicolau, Maio, Santiago, Fogo, and Brava) (Figure 1c) and they are grouped into two main types: (i) Ca-carbonatites (the most dominant type) and (ii) Mg-carbonatites. S. Vicente presents the largest exposed carbonatites, which occur either as an intrusive or extrusive type [22], similar to Brava Island [63]. Carbonatites on Fogo Islands occur in the basement and they are all coarsegrained Ca-carbonatites (sövite), while on Santiago and Maio, Mg-carbonatites are also present [20]. Carbonatites on the Secos islets near Brava Island and on S. Nicolau Island have also been described [64].

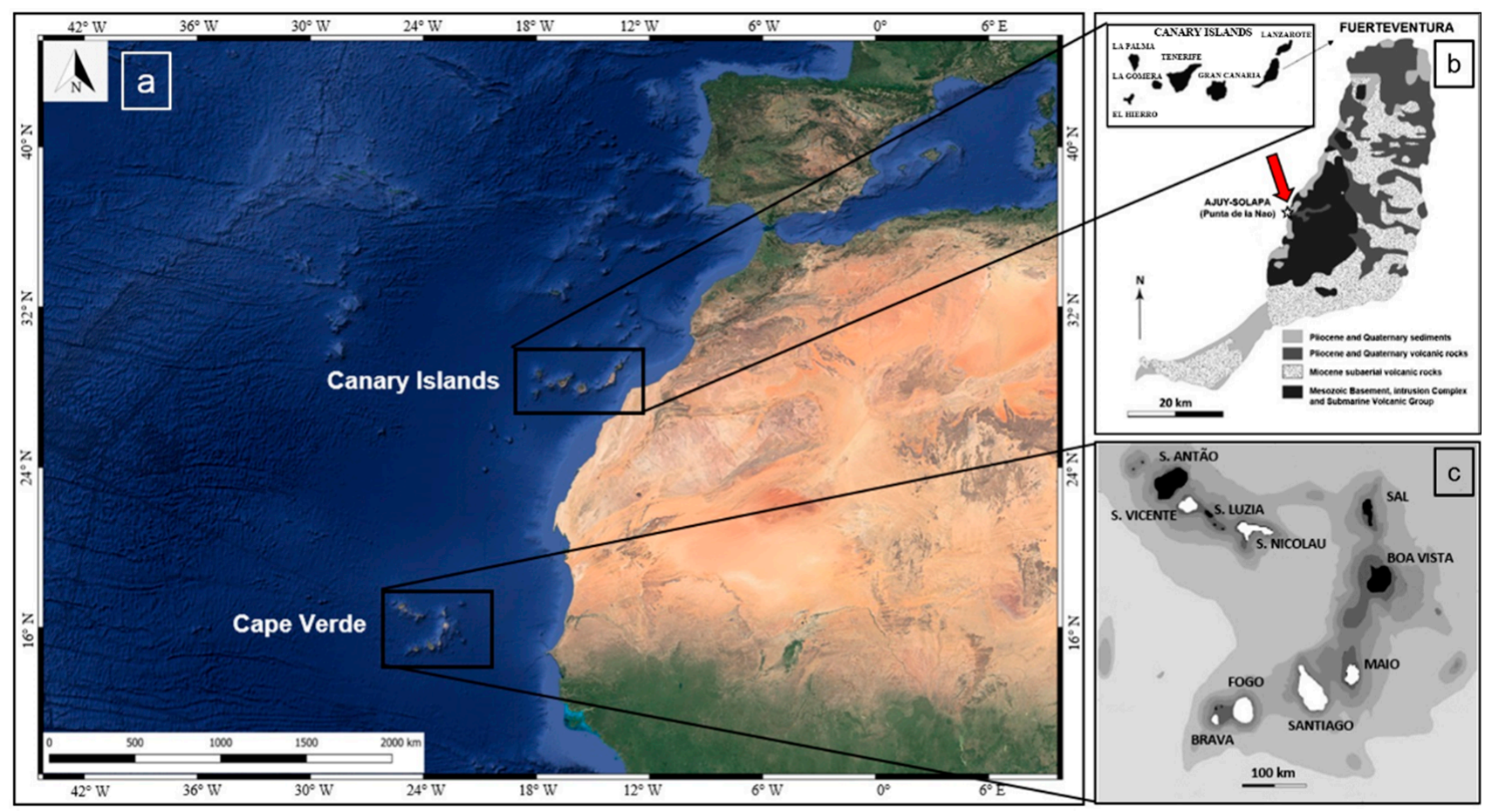

Figure 1. (a) Canary Islands and Cape Verde Archipelago in their geographic contest. (b) Simplified geology map of Fuerteventura showing the location of the carbonatite-studied samples (red arrow) (modified from Sagan et al. 2020 [65]) and (c) detail of the Cape Verde Archipelago, where the islands on which carbonatites are present are shown in white (modified from Mata et al. 2010 [23]).

\subsection{Geochemistry}

Despite that both Fuerteventura and Cape Verde oceanic carbonatites are characterized by a large variability in minor and trace element compositions, they show broadly similar trace element characteristics [20]. Indeed, it has been recognized in both the carbonatitic complexes a depletion in $\mathrm{Rb}, \mathrm{K}, \mathrm{Hf}, \mathrm{Zr}$, and $\mathrm{Ti}$, coupled to an enrichment in $\mathrm{Ba}, \mathrm{Th}, \mathrm{U}, \mathrm{Sr}$, Y, LREE, and MREE, especially if compared with OIB, although elements such as Th, U, $\mathrm{Nb}$, and Ta normally show differences in their relative abundances, interpreted as due to pyrochlore fractionation/accumulation [20].

Hoernle et al. (2002) [20] proposed that calcio-carbonatites from Fuerteventura, similar to the calcio-carbonatites from Cape Verde, result from melting of secondary Ca-carbonate belonging to recycled $1.6 \mathrm{Ga}$ oceanic crust. Furthermore, coupling $\mathrm{Ce}$ and $\mathrm{Nd}$ isotopic data, Doucelance et al. (2014) [14] suggested the recycling of marine carbonates in the source region of the Cape Verde oceanic carbonatites. In the same way, a recent study 
on Ca isotopes of carbonatites (tracers of subducted sedimentary material) confirmed the recycled marine carbonate contribution to Fuerteventura and Cape Verde carbonatite petrogenesis [66]. Although there are several models that underline the importance of recycling of marine carbonates and the oceanic crust in carbonatite origin, other hypotheses involving a primary deep-seated signature $[21,23]$ suggest a role of primordial carbon in the origin of the oceanic carbonatite source.

As regards the Cape Verde carbonatites, there is no unique viewpoint. De Ignacio et al. (2012) [22] suggest that Ca-carbonatites from São Vicente (northern Cape Verde Islands) represent fractionated melts from parental nephelinitic magma (although the authors also recognize the importance of a high-temperature immiscibility process in the petrogenesis of São Vicente Ca-carbonatites). Other models in which the Ca-carbonatites result from liquid immiscibility (and not from extreme fractionation of carbonated silicate parental magma) were also proposed for Brava, one of the southern Cape Verde Islands [25]. A1though in some cases (e.g., Fogo and Santiago islands) isotopic compositions ( $\mathrm{Sr}-\mathrm{Nd}-\mathrm{Pb}$ ) of carbonatites significantly differ from those of their associated alkaline silicate rocks, the close association of carbonatites with evolved alkaline silica-undersaturated magmas suggests a common origin. Indeed, a recent study proposes that both oceanic carbonatites (Cape Verde and Fuerteventura carbonatites) occur where primitive silicate melts have the lowest silica and highest alkali contents, driving the liquid line of descent into the silicate-carbonatite miscibility gap [67].

With respect to the continental carbonatites, Fuerteventura oceanic carbonatites present a much narrower spread in the ${ }^{143} \mathrm{Nd} /{ }^{144} \mathrm{Nd}$ vs ${ }^{87} \mathrm{Sr} /{ }^{86} \mathrm{Sr}$ diagram [20,21]. Regarding $\mathrm{Pb}$ isotopic compositions, carbonatites instead plot in a relatively large range, and initial ${ }^{207} \mathrm{~Pb} /{ }^{204} \mathrm{~Pb}$ ratios plot below the trend of the Northern Hemisphere Reference Line (NHRL) [67], which is normal for oceanic carbonatites (initial ${ }^{207} \mathrm{~Pb} /{ }^{204} \mathrm{~Pb}$ ratios of the Cape Verde carbonatites also plot below the NHRL (Hoernle et al. 2002 [20], their Figure 6)) and OIB [20,68].

Given the close similarity in isotopic compositions between Cape Verde and Fuerteventura oceanic carbonatites with Tamazert continental carbonatites (Morocco, ca. $970 \mathrm{~km}$ north-eastwards from Fuerteventura), a common source for the latter was also proposed [69], emphasizing the invoked eastward deflection of the Canary mantle plume head through a sub-continental lithospheric corridor from the eastern Atlantic to the middle Atlas mountain chain and the western Mediterranean [70].

Lastly, Mata et al. (2010) [23] reported the first noble gas results obtained for Cape Verde carbonatites, and some of the analysed calcite and apatite minerals present high ${ }^{3} \mathrm{He} /{ }^{4} \mathrm{He}$ ratios (R/Ra up to 15.5 and 9.76, respectively), suggesting a contribution of He from a deep and more primitive mantle (plume-type) for Cape Verde carbonatites.

\section{Analytical Methods}

Noble gas isotopic ratios $(\mathrm{He}, \mathrm{Ne}, \mathrm{Ar})$ were determined for calcite, apatite, and clinopyroxene mineral separates from Fuerteventura carbonatites. Clinopyroxenes from a clinopyroxenite adjacent to Fuerteventura carbonatites were also analysed. Calcites were concentrated using a Frantz isodynamic separator. Apatite and clinopyroxene were concentrated using magnetic methods and magnetic heavy liquid separation (sodium polytungstate) and were finally refined by handpicking.

Noble gas isotopic analyses were carried out at Istituto Nazionale di Geofisica e Vulcanologia (INGV-Palermo) following the preparation and analytical protocols described in Rizzo et al. $(2018,2019)$ [71,72]. Phenocrysts were cleaned in acetone and millipore water by using an ultrasonic bath, and the portion of the selected sample material was loaded into a stainless-steel crusher baked for $48-72 \mathrm{~h}$ at $120^{\circ} \mathrm{C}$ in order to achieve ultra-high-vacuum conditions $\left(10^{-9} \mathrm{mbar}\right)$. Fluid inclusions from minerals were released by in-vacuum singlestep crushing, and the external pressure applied to the minerals by the hydraulic press was 250 bar. Noble gases were separated from the other volatiles by using a "cold finger" immersed in liquid nitrogen $\left(\mathrm{T}=-196^{\circ} \mathrm{C}\right)$ that allows freezing of $\mathrm{H}_{2} \mathrm{O}$ and $\mathrm{CO}_{2}$ and were 
successively further cleaned in an ultra-high vacuum $\left(10^{-9}-10^{-10} \mathrm{mbar}\right)$ purification line, and all the species of the gas mixture, except noble gases, were removed using four getters. Helium $\left({ }^{3} \mathrm{He}\right.$ and $\left.{ }^{4} \mathrm{He}\right)$ and neon $\left({ }^{20} \mathrm{Ne}\right)$ isotopes were measured separately by two different split-flight-tube mass spectrometers (Helix SFT-Thermo). The analytical uncertainty of the He isotopic ratio was $\leq 4 \%$, while that for ${ }^{20} \mathrm{Ne} /{ }^{22} \mathrm{Ne}$ and ${ }^{21} \mathrm{Ne} /{ }^{22} \mathrm{Ne}$ was $<2 \%$ and $<4 \%$, respectively. The $\mathrm{Ne}$ isotope ratios were corrected for isobaric interferences at $\mathrm{m} / \mathrm{z}$ values of $20\left({ }^{40} \mathrm{Ar}^{2+}\right)$ and $22\left({ }^{44} \mathrm{CO}_{2}{ }^{2+}\right)$. Corrections were generally carried out by measuring ${ }^{20} \mathrm{Ne}$, ${ }^{21} \mathrm{Ne},{ }^{22} \mathrm{Ne},{ }^{40} \mathrm{Ar}$, and ${ }^{44} \mathrm{CO}_{2}$ during the same analyses and considering the previously determined ${ }^{40} \mathrm{Ar}^{2+} /{ }^{40} \mathrm{Ar}^{+}$and ${ }^{44} \mathrm{CO}_{2}{ }^{2+} / \mathrm{CO}_{2}{ }^{+}$ratios under static conditions on the same Helix-SFT mass spectrometers used to perform Ne measurements. Argon isotopes $\left({ }^{36} \mathrm{Ar}\right.$, ${ }^{38} \mathrm{Ar}$, and ${ }^{40} \mathrm{Ar}$ ) were analysed by a multi-collector mass spectrometer (GVI Argus) with an analytical uncertainty $1 \%$. The uncertainty in the determinations of $\mathrm{He}, \mathrm{Ne}$, and $\mathrm{Ar}$ elemental contents was less than $5 \%$. More details about the sample preparation and analytical procedures are available in Rizzo et al. $(2018,2019)[71,72]$.

Whole-rock analyses of Fuerteventura carbonatites were performed at the ALS Geochemistry Laboratory.

The trace element composition of the minerals and rocks from Fuerteventura carbonatites was analysed at the INGV laboratory-Palermo using a GeoLasPro 193nm ArFExcimer laser ablation (LA) system connected to an Agilent 7500ce quadrupole ICP-MS. The analyses were performed with a constant laser repetition rate of $10 \mathrm{~Hz}$, a fluency of 14-15 $\mathrm{J} / \mathrm{cm}^{2}$, a He flux of about $0.8 \mathrm{~L} / \mathrm{min}$ in the ablation cell, and a $32-44 \mu \mathrm{m}$ spot. Glass reference material NIST612 was used as an external standard for all the clinopyroxene and apatite minerals whereas the Microanalytical Carbonate Standard MACS3 was used for calcite minerals. ${ }^{43} \mathrm{Ca}$, estimated by ESEM measures, was used as an internal standard for all samples. The analytical accuracy was calculated by repeated analyses of the USGS basaltic reference glass BCR-2G for the clinopyroxene and apatite minerals and of the glass reference material NIST612 for calcite minerals; it was $\leq 15 \%$ for most of the elements. The analytical precision was estimated by repeated analyses of the reference material NIST612 and the MACS3 carbonate standard and was $\leq 20 \%$ for most of the elements.

\section{Results}

\subsection{Petrography}

Based on petrographic characteristics, Fuerteventura carbonatites are grouped into two main types: (i) calcio-carbonatites (the most dominant type) and (ii) silico-carbonatites, when the amount of silicate phases reach up to $50 \%$ of the rock volume. Fuerteventura carbonatites are medium-(microsövite) to coarse-grained (sövite) (Figure 2a) and they are composed of calcite, with variable amounts of clinopyroxene (aegirine-augite), feldspar, biotite, Fe- and Ti-oxides and accessory minerals such as apatite, pyrochlore, titanite, barite, and zircon.

Calcite occurs as euhedral to sub-euhedral grains with typical rhombohedral cleavage (Figure 2b). Tabular calcite phenocrysts are common, forming aggregates with $120^{\circ}$ grain boundaries angle (Figure 2c). Occasionally (e.g., in the Punta de la Nao area) they also occur as elongated calcite crystals arranged in a spinifex-like texture. The occurrence at Punta de la Nao of both tabular calcite and typical spinifex textures reflects the magmatic origin of non-recrystallized carbonatite.

Apatite is largely the most abundant accessory phase typically found in rounded grains or elongated prisms with a typical igneous tapered pill-like shape. Furthermore, apatite is commonly enclosed either by calcite or other silicate phases, in poikilitic textures, suggesting that apatite is the liquidus phase. Other common accessory minerals are pyrochlore, which occurs as small-zoned microphenocrysts, and zircon, less abundant than apatite and pyrochlore, but it occurs in size larger than the latter (up to 1-2 mm) (Figure 2d). 

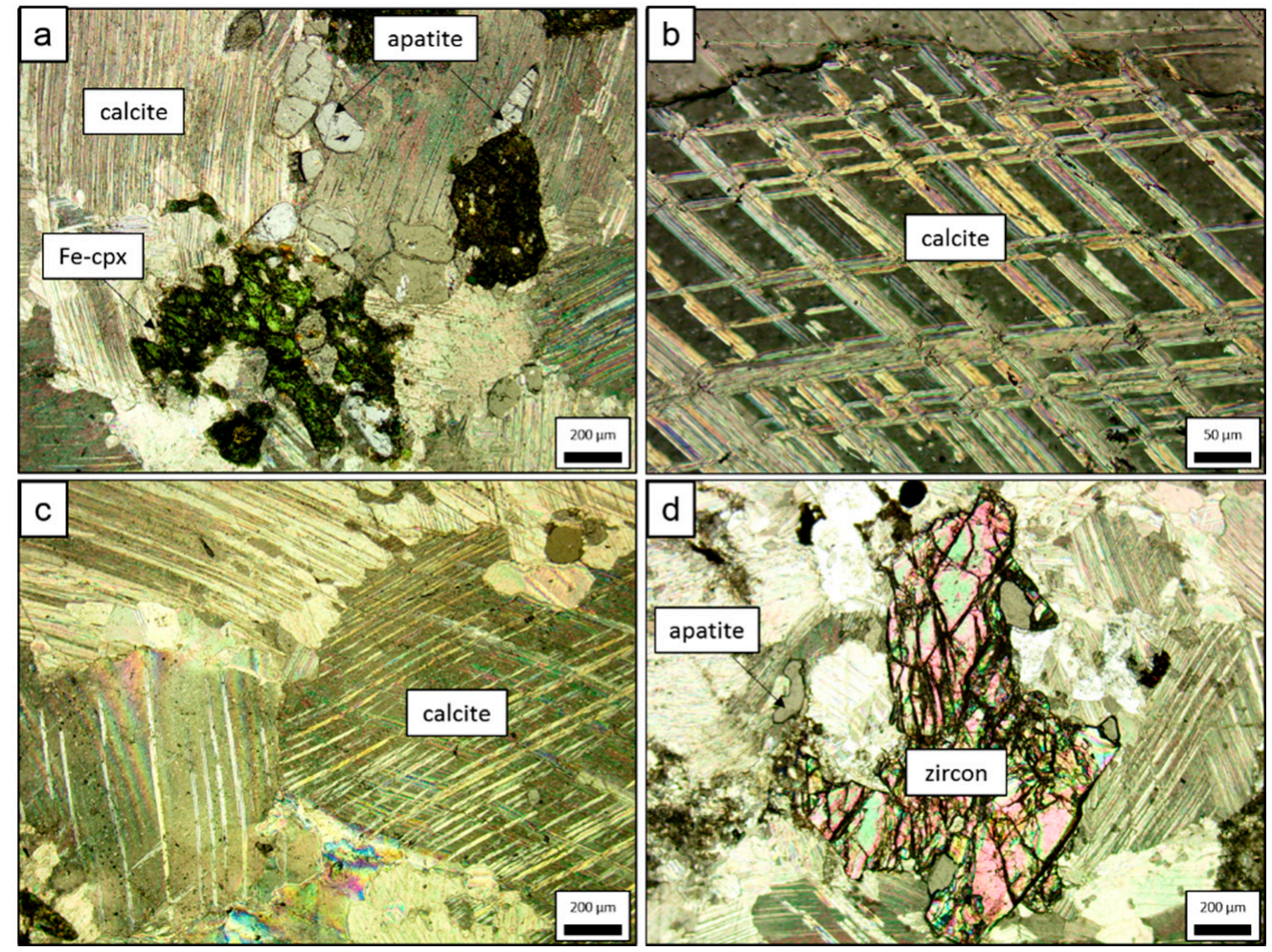

Figure 2. Microscopic aspects of Fuerteventura carbonatite textures (crossed polars). (a) Coarsegrained carbonatite (sövite) with Fe-clinopyroxene (dark green), calcite, and associated euhedralrounded apatite (light grey, top center). (b) Detail of different grain-sizes of calcite with typical rhombohedral cleavage. (c) Calcite aggregates with a $120^{\circ}$ grain boundary angle in coarse-grained carbonatite. (d) Zircon crystal in a medium-grained carbonatite (microsövite).

\subsection{Major and Trace Elements}

The major and trace element compositions of Fuerteventura carbonatites (whole-rock) are reported in Table 1. Table 2 reports trace element contents in calcite and apatite from Fuerteventura carbonatites, while Table 3 reports trace elements in clinopyroxenes from Fuerteventura carbonatites and clinopyroxenite.

Table 1. Major and trace element compositions of Fuerteventura whole-rock carbonatites.

\begin{tabular}{ccc}
\hline Occurrence & \multicolumn{3}{c}{ Fuerteventura } \\
\hline Sample & FUE1-03 & FUE1-04 \\
\hline $\mathrm{SiO}_{2}($ wt. $\%)$ & 11.55 & 12.8 \\
$\mathrm{TiO}_{2}$ & 0.13 & 0.45 \\
$\mathrm{Al}_{2} \mathrm{O}_{3}$ & 1.9 & 3.33 \\
$\mathrm{Fe}_{2} \mathrm{O}_{3 \mathrm{t}}$ & 4.04 & 3.9 \\
$\mathrm{MnO}$ & 0.31 & 0.32 \\
$\mathrm{MgO}$ & 1.29 & 1.19 \\
$\mathrm{CaO}$ & 43.8 & 41.9 \\
$\mathrm{Na} \mathrm{O}_{2}$ & 1.5 & 1.66 \\
$\mathrm{~K}_{2} \mathrm{O}$ & 0.34 & 0.37 \\
$\mathrm{P}_{2} \mathrm{O}_{5}$ & 3.01 & 2.23 \\
$\mathrm{LOI}$ & 30.4 & 29.8 \\
$\mathrm{Total}$ & 98.27 & 97.95 \\
$\mathrm{Sr}(\mathrm{ppm})$ & 15,900 & 14,300 \\
$\mathrm{Y}$ & 142.5 & 129.5 \\
$\mathrm{Rb}$ & 10.4 & 15.1 \\
$\mathrm{Ba}$ & 659 & 428 \\
\hline
\end{tabular}


Table 1. Cont.

\begin{tabular}{|c|c|c|}
\hline \multirow{2}{*}{$\begin{array}{c}\text { Occurrence } \\
\text { Sample }\end{array}$} & \multicolumn{2}{|c|}{ Fuerteventura } \\
\hline & FUE1-03 & FUE1-04 \\
\hline $\mathrm{La}$ & 589 & 487 \\
\hline $\mathrm{Ce}$ & 1205 & 1025 \\
\hline $\operatorname{Pr}$ & 140 & 122 \\
\hline $\mathrm{Nd}$ & 487 & 419 \\
\hline $\mathrm{Sm}$ & 71.6 & 62.3 \\
\hline $\mathrm{Eu}$ & 21.6 & 18.2 \\
\hline Gd & 53.7 & 46.8 \\
\hline $\mathrm{Tb}$ & 6.6 & 5.6 \\
\hline Dy & 32.4 & 28.8 \\
\hline Ho & 5.3 & 4.9 \\
\hline Er & 13.1 & 10.9 \\
\hline $\mathrm{Tm}$ & 1.4 & 1.3 \\
\hline $\mathrm{Yb}$ & 9.1 & 8.05 \\
\hline $\mathrm{Lu}$ & 1.3 & 1.1 \\
\hline $\mathrm{Hf}$ & 3.7 & 8.4 \\
\hline $\mathrm{Zr}$ & 424 & 755 \\
\hline $\mathrm{Pb}$ & 8 & 10 \\
\hline Th & 33.2 & 21.8 \\
\hline $\mathrm{U}$ & 3.7 & 3.7 \\
\hline $\mathrm{Nb}$ & 63.7 & 378 \\
\hline$\sum \mathrm{REE}$ & 2637.1 & 2241.0 \\
\hline $\mathrm{Th} / \mathrm{U}$ & 8.9 & 5.9 \\
\hline$(\mathrm{La} / \mathrm{Yb})_{\mathrm{N}}$ & 46.4 & 43.4 \\
\hline $\mathrm{Eu} / \mathrm{Eu}^{*}$ & 1.02 & 0.99 \\
\hline $\mathrm{Sr} / \mathrm{Sr}^{*}$ & 23.37 & 22.75 \\
\hline
\end{tabular}

Note. $\mathrm{Eu}^{*}=\mathrm{Eu}_{\mathrm{N}} /\left(\mathrm{Sm}_{\mathrm{N}} \times \mathrm{Gd}_{\mathrm{N}}\right)^{1 / 2} ; \mathrm{Sr}^{*}=\left(\mathrm{Ce}_{\mathrm{N}}+\mathrm{Nd}_{\mathrm{N}}\right)^{1 / 2}$.

Table 2. Representative trace element compositions of calcite and apatite in Fuerteventura carbonatites.

\begin{tabular}{cccc}
\hline Occurrence & \multicolumn{3}{c}{ Fuerteventura } \\
\hline Mineral & Calcite \\
\hline Sample & FUE1-03 & FUE1-04 & FUE3-01 \\
\hline Mn $($ ppm $)$ & 1545.56 & 1422.88 & 2225.86 \\
$\mathrm{Sr}$ & $25,643.40$ & $25,341.66$ & $26,331.39$ \\
$\mathrm{Y}$ & 116.59 & 121.32 & 124.79 \\
$\mathrm{Rb}$ & 0.07 & 0.07 & 0.93 \\
$\mathrm{Ba}$ & 721.41 & 989.64 & 607.97 \\
$\mathrm{La}$ & 607.83 & 624.27 & 453.81 \\
$\mathrm{Ce}$ & 1092.91 & 1116.05 & 896.40 \\
$\mathrm{Pr}$ & 104.27 & 105.67 & 81.12 \\
$\mathrm{Nd}$ & 355.19 & 361.49 & 288.65 \\
$\mathrm{Sm}$ & 50.47 & 51.06 & 42.99 \\
$\mathrm{Eu}$ & 14.45 & 14.84 & 12.30 \\
$\mathrm{Gd}$ & 39.12 & 40.06 & 41.11 \\
$\mathrm{~Tb}$ & 4.46 & 4.55 & 4.43 \\
$\mathrm{Dy}$ & 23.09 & 23.70 & 23.66 \\
$\mathrm{Ho}$ & 4.16 & 4.27 & 4.25 \\
$\mathrm{Er}$ & 10.39 & 10.70 & 10.73 \\
$\mathrm{Tm}$ & 1.26 & 1.31 & 1.38 \\
$\mathrm{Yb}$ & 7.29 & 7.62 & 8.29 \\
$\mathrm{Lu}$ & 1.02 & 1.06 & 1.15 \\
$\mathrm{Hf}$ & 0.01 & 0.01 & 0.02 \\
$\mathrm{Zr}$ & 0.03 & 0.04 & 0.78 \\
$\mathrm{~Pb}$ & 5.77 & 5.31 & 6.03 \\
$\mathrm{Th}$ & 0.04 & 0.07 & \\
\hline & & & \\
\hline
\end{tabular}


Table 2. Cont.

\begin{tabular}{|c|c|c|c|c|}
\hline Occurrence & \multicolumn{4}{|c|}{ Fuerteventura } \\
\hline Mineral & \multicolumn{4}{|c|}{ Calcite } \\
\hline Sample & FUE1-03 & \multicolumn{2}{|l|}{ FUE1-04 } & FUE3-01 \\
\hline $\mathrm{U}$ & $<0.1$ & \multicolumn{2}{|l|}{$<0.1$} & 1.45 \\
\hline $\mathrm{Nb}$ & 0.01 & \multicolumn{2}{|l|}{0.02} & 2.12 \\
\hline$\sum \mathrm{REE}$ & 2315.90 & \multicolumn{2}{|l|}{2366.64} & 1870.28 \\
\hline Th/U & 10.03 & \multicolumn{2}{|l|}{16.60} & 5.94 \\
\hline$(\mathrm{La} / \mathrm{Yb})_{\mathrm{N}}$ & 59.86 & \multicolumn{2}{|l|}{58.79} & 39.27 \\
\hline $\mathrm{Eu} / \mathrm{Eu}^{*}$ & 0.96 & \multicolumn{2}{|l|}{0.97} & 0.88 \\
\hline $\mathrm{Sr} / \mathrm{Sr}^{*}$ & 41 & \multicolumn{2}{|l|}{40.11} & 46.55 \\
\hline$\delta \mathrm{Ce}$ & 0.98 & \multicolumn{2}{|l|}{0.97} & 1.06 \\
\hline$\delta \mathrm{Eu}$ & 0.96 & \multicolumn{2}{|l|}{0.97} & 0.88 \\
\hline$\delta \mathrm{Y}$ & 0.95 & \multicolumn{2}{|l|}{0.97} & 0.99 \\
\hline Occurrence & \multicolumn{4}{|c|}{ Fuerteventura } \\
\hline Mineral & \multicolumn{4}{|c|}{ Apatite } \\
\hline Sample & FUE1-03 & \multicolumn{3}{|c|}{ FUE1-04 } \\
\hline Mn (ppm) & 353.28 & \multicolumn{3}{|c|}{427.57} \\
\hline $\mathrm{Sr}$ & $14,243.53$ & \multicolumn{3}{|c|}{$14,520.67$} \\
\hline $\mathrm{Y}$ & 770.19 & \multicolumn{3}{|c|}{776.35} \\
\hline $\mathrm{Rb}$ & 0.13 & \multicolumn{3}{|c|}{0.15} \\
\hline $\mathrm{Ba}$ & 23.78 & \multicolumn{3}{|c|}{27.38} \\
\hline $\mathrm{La}$ & 3166.94 & \multicolumn{3}{|c|}{3269.77} \\
\hline $\mathrm{Ce}$ & 7619.98 & & 7598.89 & \\
\hline $\operatorname{Pr}$ & 904.29 & & 914.20 & \\
\hline $\mathrm{Nd}$ & 3517.07 & & 3603.46 & \\
\hline $\mathrm{Sm}$ & 494.68 & & 498.70 & \\
\hline $\mathrm{Eu}$ & 132.34 & & 131.24 & \\
\hline $\mathrm{Gd}$ & 443.72 & & 396.08 & \\
\hline $\mathrm{Tb}$ & 42.72 & & 40.93 & \\
\hline Dy & 200.23 & & 198.20 & \\
\hline Ho & 29.35 & & 29.96 & \\
\hline $\mathrm{Er}$ & 63.53 & & 63.55 & \\
\hline $\mathrm{Tm}$ & 6.77 & & 6.72 & \\
\hline $\mathrm{Yb}$ & 33.92 & & 34.17 & \\
\hline $\mathrm{Lu}$ & 3.83 & & 3.74 & \\
\hline Hf & 0.10 & & 0.06 & \\
\hline $\mathrm{Zr}$ & 17.61 & & 13.35 & \\
\hline $\mathrm{Pb}$ & 2.23 & & 2.27 & \\
\hline Th & 347.35 & & 333.71 & \\
\hline $\mathrm{U}$ & 39.72 & & 34.36 & \\
\hline $\mathrm{Nb}$ & 7.68 & & 5.96 & \\
\hline$\sum \mathrm{REE}$ & $16,659.36$ & & $16,789.61$ & \\
\hline $\mathrm{Th} / \mathrm{U}$ & 8.74 & & 9.71 & \\
\hline$(\mathrm{La} / \mathrm{Yb})_{\mathrm{N}}$ & 63.41 & & 65.01 & \\
\hline $\mathrm{Eu} / \mathrm{Eu}^{*}$ & 0.85 & & 0.87 & \\
\hline $\mathrm{Sr} / \mathrm{Sr}^{*}$ & 8.13 & & 8.25 & \\
\hline$\delta \mathrm{Ce}$ & 1.08 & & 1.05 & \\
\hline$\delta \mathrm{Eu}$ & 0.84 & & 0.86 & \\
\hline$\delta \mathrm{Y}$ & 0.82 & & 0.82 & \\
\hline
\end{tabular}

Note. See Section 5.1.1 in the text for $\delta \mathrm{Ce}, \delta \mathrm{Eu}$ and $\delta \mathrm{Y}$ calculation. 
Table 3. Representative trace element compositions of clinopyroxene in Fuerteventura carbonatites and clinopyroxenite.

\begin{tabular}{|c|c|c|c|c|}
\hline \multirow{2}{*}{$\begin{array}{c}\text { Rock Type } \\
\text { Mineral }\end{array}$} & \multicolumn{2}{|c|}{ Carbonatite } & \multicolumn{2}{|c|}{ Clinopyroxenite } \\
\hline & \multicolumn{2}{|c|}{ Clinopyroxene } & & \\
\hline Sample & FUE3-01 & FUE3-01 ${ }^{1}$ & FUE4-03 & FUE4-03 $^{1}$ \\
\hline Sc (ppm) & 4.35 & 3.32 & 62.05 & 65.68 \\
\hline $\mathrm{V}$ & 62.04 & 53.54 & 327.90 & 275.10 \\
\hline $\mathrm{Cr}$ & 14.68 & 13.78 & 248.88 & 859.38 \\
\hline Co & 9.46 & 7.89 & 44.34 & 46.15 \\
\hline $\mathrm{Ni}$ & 12.59 & 10.89 & 214.97 & 300.33 \\
\hline $\mathrm{Zn}$ & 106.20 & 89.90 & 35.68 & 31.84 \\
\hline $\mathrm{Sr}$ & 271.97 & 245.87 & 134.06 & 87.66 \\
\hline $\mathrm{Y}$ & 18.07 & 15.06 & 18.76 & 10.34 \\
\hline $\mathrm{Zr}$ & 134.15 & 124.23 & 128.87 & 52.43 \\
\hline $\mathrm{Nb}$ & 6.75 & 5.25 & 0.69 & 0.41 \\
\hline $\mathrm{Rb}$ & 16.36 & 15.87 & 0.26 & 0.27 \\
\hline $\mathrm{Ba}$ & 28.22 & 26.46 & 0.13 & 0.05 \\
\hline $\mathrm{La}$ & 60.29 & 71.21 & 6.93 & 2.95 \\
\hline $\mathrm{Ce}$ & 49.46 & 50.98 & 26.19 & 12.27 \\
\hline $\operatorname{Pr}$ & 9.27 & 5.87 & 4.71 & 2.29 \\
\hline $\mathrm{Nd}$ & 25.58 & 20.98 & 28.30 & 13.58 \\
\hline $\mathrm{Sm}$ & 7.94 & 8.97 & 7.87 & 4.09 \\
\hline $\mathrm{Eu}$ & 2.03 & 2.07 & 2.20 & 1.28 \\
\hline $\mathrm{Gd}$ & 6.53 & 7.11 & 7.87 & 3.80 \\
\hline $\mathrm{Tb}$ & 0.68 & 0.87 & 0.85 & 0.50 \\
\hline Dy & 3.58 & 4.01 & 4.81 & 2.81 \\
\hline Ho & 0.66 & 0.77 & 0.77 & 0.49 \\
\hline $\mathrm{Er}$ & 1.65 & 1.75 & 1.61 & 0.95 \\
\hline $\mathrm{Tm}$ & 0.21 & 0.32 & 0.20 & 0.13 \\
\hline $\mathrm{Yb}$ & 1.44 & 1.56 & 1.06 & 0.61 \\
\hline $\mathrm{Lu}$ & 0.21 & 0.32 & 0.14 & 0.08 \\
\hline Hf & 2.13 & 2.15 & 6.31 & 2.57 \\
\hline $\mathrm{Ta}$ & 0.79 & 0.87 & 0.16 & 0.06 \\
\hline $\mathrm{Pb}$ & 7.27 & 7.35 & 0.07 & 0.12 \\
\hline Th & 1.21 & 0.89 & 0.06 & 0.04 \\
\hline U & 4.36 & 1.90 & 0.02 & $<0.01$ \\
\hline$\sum \mathrm{REE}$ & 169.52 & 176.79 & 93.52 & 45.83 \\
\hline $\mathrm{Th} / \mathrm{U}$ & 0.27 & 0.46 & 3 & 4.44 \\
\hline
\end{tabular}

Note. ${ }^{1} \mathrm{~s}$ analysis of the same sample.

Whole-rock analyses of Fuerteventura carbonatites show very small variations of $\mathrm{MgO}$ (1.2-1.3 wt.\%), $\mathrm{Fe}_{2} \mathrm{O}_{3 \mathrm{t}}$ (3.9-4.0 wt.\%), $\mathrm{Na}_{2} \mathrm{O}$ (1.5-1.6 wt.\%), $\mathrm{P}_{2} \mathrm{O}_{5}$ (2.2-3.0 wt.\%), and loss on ignition (LOI) (29.8-30.4 wt.\%), while $\mathrm{CaO}$ (41.9-43.8 wt.\%), $\mathrm{SiO}_{2}$ (11.5-12.8wt.\%), and $\mathrm{Al}_{2} \mathrm{O}_{3}(1.9-3.3 \mathrm{wt} . \%)$ show slightly more appreciable variations (Table 1).

Concentrations of calcites are similar to those determined for carbonatites, mostly Ba (up to $989 \mathrm{ppm}$ ), La (up to $624 \mathrm{ppm}$ ), and Ce (up to $1116 \mathrm{ppm}$ ), while Sr concentrations in calcites (up to 26,330 ppm) are higher than $\mathrm{Sr}$ concentrations in whole-rock sample (up to $15,900 \mathrm{ppm}$ ). Apatites show higher concentrations of REE ( $\sum$ REE up to $16,690 \mathrm{ppm}$ ) if compared to carbonatites ( $\sum R E E$ up to $2637 \mathrm{ppm}$ ), especially for the La (up to $3270 \mathrm{ppm}$ ), Ce (up to $7620 \mathrm{ppm}$ ), Pr (up to $914 \mathrm{ppm}$ ), and Nd (up to $3603 \mathrm{ppm}$ ) contents (Table 2). In the same way, clinopyroxenes from carbonatites show also different concentrations than whole-rock samples, with REE concentrations ( $\sum$ REE up to $177 \mathrm{ppm}$ ) lower than carbonatites. Moreover, if compared with clinopyroxenes from Fuerteventura clinopyroxenite, clinopyroxenes from carbonatites present some differences on trace element concentrations, especially for Sc, $\mathrm{V}, \mathrm{Cr}, \mathrm{Co}$, and $\mathrm{Ni}$ abundances (Table 3). Th is normally more abundant than $\mathrm{U}$ in whole-rock samples, with $\mathrm{Th} / \mathrm{U}$ ratios ranging from 5.9 to 8.9. It is the same for apatite and calcite minerals, with $\mathrm{Th} / \mathrm{U}$ ratios ranging from 5 to 17 in calcite and from 8 
to 10 in apatite. On the contrary, clinopyroxene presents $\mathrm{U}$ concentrations higher than $\mathrm{Th}$ concentrations, with $\mathrm{Th} / \mathrm{U}$ ratios up to 0.5 .

\subsection{Noble Gas (He, Ne, Ar) Isotopes}

In this study, we measured the $\mathrm{He}, \mathrm{Ne}$, and Ar isotopic compositions in minerals of calcite, clinopyroxene, and apatite in Fuerteventura carbonatites and clinopyroxene in a clinopyroxenite. Furthermore, in order to better understand the significance of ${ }^{3} \mathrm{He} /{ }^{4} \mathrm{He}$ ratios for calcite, apatite, and clinopyroxene separates from Fuerteventura carbonatites and from clinopyroxenite, we calculated the radiogenic ${ }^{4} \mathrm{He}^{*}$ in situ produced by Th and $\mathrm{U}$ decay (Table 4). Noble gas concentrations and isotopic ratios of mineral separates from Fuerteventura carbonatites and Fuerteventura clinopyroxenite are shown in Table 5.

Calcite is characterized by ${ }^{4} \mathrm{He}$ concentrations in a restricted range of $5.7 \times 10^{-7}$ to $15.2 \times 10^{-7} \mathrm{ccSTP} / \mathrm{g}$; in contrast, we measured high ${ }^{4} \mathrm{He}$ in the apatite, from $51.6 \times 10^{-7}$ to $22.1 \times 10^{-6} \mathrm{ccSTP} / \mathrm{g}$ (Table 5). Therefore, high concentrations of ${ }^{4} \mathrm{He}$ in the apatite are associated with a very low signature of the ${ }^{3} \mathrm{He} /{ }^{4} \mathrm{He}$ ratios in the same minerals that range from $3 \times 10^{-9}$ to $8 \times 10^{-8}$, and they correspond to R/Ra from 0.003Ra to 0.08Ra (Table 5). We analysed only one sample of clinopyroxene in carbonatite and one in the clinopyroxenite; the ${ }^{4} \mathrm{He}$ concentrations are $4.96 \times 10^{-7} \mathrm{ccSTP} / \mathrm{g}$ and $0.83 \times 10^{-7} \mathrm{ccSTP} / \mathrm{g}$, respectively (Table 5). The He isotopic ratios in clinopyroxene from carbonatite $(\mathrm{R} / \mathrm{Ra}=2.23)$ are lower than calcite $(\mathrm{R} / \mathrm{Ra}=3.86)$, while clinopyroxene from clinopyroxenite shows the highest He isotopic ratios $(6.66 \mathrm{Ra})$. The ${ }^{4} \mathrm{He} /{ }^{20} \mathrm{Ne}$ in all the analysed samples is at least three order of magnitude higher than the same ratio in the atmosphere $\left({ }^{4} \mathrm{He} /{ }^{20} \mathrm{Ne}=0.318\right.$ [73]), and this indicates that the He air component of $\mathrm{He}$ is negligible in all the samples.

${ }^{20} \mathrm{Ne} /{ }^{22} \mathrm{Ne}$ and ${ }^{21} \mathrm{Ne} /{ }^{22} \mathrm{Ne}$ ratios from calcite (up to 10.02 and 0.0302 , respectively) and apatite (up to 10.12 and 0.0297, respectively) are a little higher than the air ratio (Table 5). Clinopyroxene from carbonatite presents ${ }^{20} \mathrm{Ne} /{ }^{22} \mathrm{Ne}$ and ${ }^{21} \mathrm{Ne} /{ }^{22} \mathrm{Ne}$ ratios of 10.02 and 0.0301 , while clinopyroxenes from clinopyroxenite show ${ }^{20} \mathrm{Ne} /{ }^{22} \mathrm{Ne}$ and ${ }^{21} \mathrm{Ne} /{ }^{22} \mathrm{Ne}$ ratios of 9.95 and 0.0295 , in both cases slightly higher than the air ratio (Table 5).

The ${ }^{40} \mathrm{Ar} /{ }^{36} \mathrm{Ar}$ isotopic ratios (Table 5) are always higher than atmospheric value of $298.6 \pm 0.3$ [74] for all mineral separates: calcite ${ }^{40} \mathrm{Ar} /{ }^{36} \mathrm{Ar}$ ranges from 614 to 2068, apatite from 409 to 690 , and clinopyroxene in carbonatite and clinopyroxenite are 650 and 431 , respectively.

Table 4. Th and $\mathrm{U}$ concentrations and related ${ }^{4} \mathrm{He}^{*}$ production in mineral separates from Fuerteventura carbonatites and clinopyroxenite.

\begin{tabular}{|c|c|c|c|c|}
\hline Mineral Type & Th (ppm) & $\mathrm{U}(\mathrm{ppm})$ & Age (Ma) & ${ }^{4} \mathrm{He}^{*}(\mu \mathrm{ccSTP} / \mathrm{g})$ \\
\hline \multicolumn{5}{|l|}{ Carbonatite } \\
\hline \multicolumn{5}{|l|}{ Apatite } \\
\hline FUE1-03 & 347.3 & 39.7 & 25 & 7.3 \\
\hline FUE1-04 & 333.7 & 34.3 & 25 & 6.7 \\
\hline \multicolumn{5}{|l|}{ Calcite } \\
\hline FUE1-03 & 0.04 & 0.004 & 25 & $<0.001$ \\
\hline FUE3-01 & 8.62 & 1.45 & 25 & 0.2 \\
\hline FUE3-01 duplicate & 2.3 & 1.1 & 25 & 0.01 \\
\hline \multicolumn{5}{|l|}{ Clinopyroxene } \\
\hline FUE3-01 & 1.2 & 4.4 & 25 & 0.3 \\
\hline \multicolumn{5}{|l|}{ Clinopyroxenite } \\
\hline \multicolumn{5}{|l|}{ Clinopyroxene } \\
\hline FUE4-03 & 0.06 & 0.02 & 22 & 0.002 \\
\hline
\end{tabular}

Note. The equation ${ }^{4} \mathrm{He}^{*} \approx 2.8 \times 10-8(4.35+\mathrm{Th} / \mathrm{U}) \times(\mathrm{U}) \times(\mathrm{t})$ was used to calculate the ${ }^{4} \mathrm{He}^{*}$ radiogenic (from Mata et al. 2010 [23]). [Th] and [U] in ppm, $t$ in Ma. 
Table 5. He concentrations (ccSTP/g) and He, Ne, and Ar isotopic ratios in mineral separates from Fuerteventura carbonatites and clinopyroxenite.

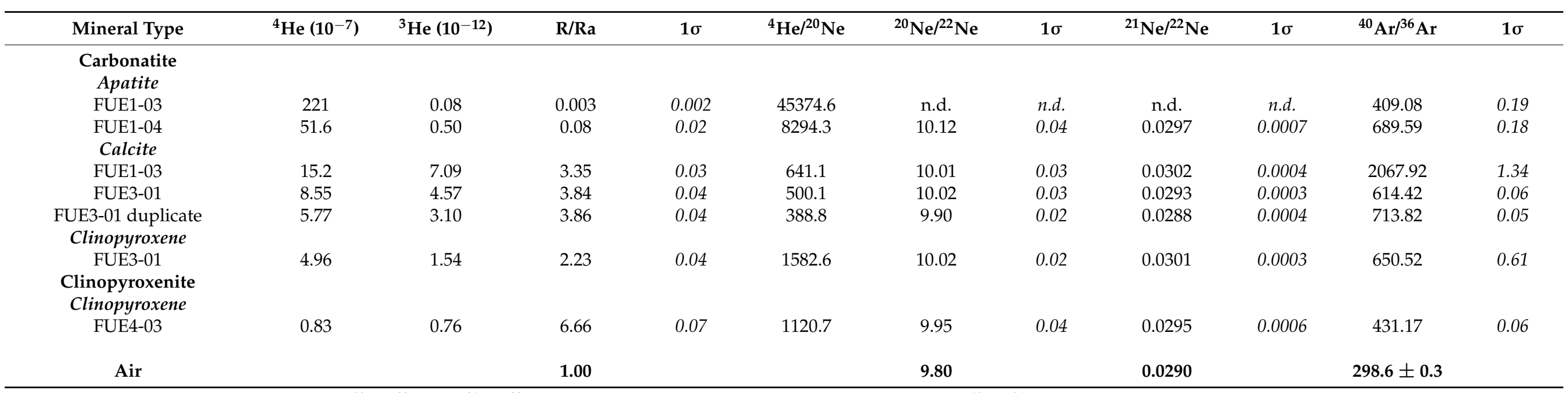

Note. The atmospheric value for ${ }^{20} \mathrm{Ne} /{ }^{22} \mathrm{Ne}$ and ${ }^{21} \mathrm{Ne} /{ }^{22} \mathrm{Ne}$ is taken from Ozima and Podosek, 2002 [73], while that for ${ }^{40} \mathrm{Ar} /{ }^{36} \mathrm{Ar}$ is taken from Lee et al. 2006 [74]. n.d. = not determined. 


\section{Discussion}

\subsection{Major and Trace Elements}

The major element data of oceanic carbonatites show a large range in $\mathrm{CaO}$ and $\mathrm{MgO}$, and this is due to the presence of two different groups, especially on Cape Verde Archipelago: (i) Ca-carbonatites with a high $\mathrm{CaO}$ and low $\mathrm{MgO}$ content and (ii) $\mathrm{Mg}$ carbonatites with a low $\mathrm{CaO}$ and high $\mathrm{MgO}$ content (Figure 2 in Hoernle et al. 2002 [20]). Although our new whole-rock analysis of Fuerteventura carbonatites shows a slightly lower $\mathrm{CaO}$ content (41.9-43.8 wt.\%) compared with literature data (48.1-51.4 wt.\% [20]), the results confirm that the studied samples are Ca-carbonatites with a low $\mathrm{MgO}$ content (up to $1.29 \mathrm{wt} . \%$ ). Our data on the major element contents of Fuerteventura carbonatites are comparable with literature data [20], with the exception of the $\mathrm{SiO}_{2}$ content that was slightly higher (11.5-12.8 wt.\%) if compared with previous values (up to $5.85 \mathrm{wt} . \%$ [20]), but this is probably due to a higher content of silicate phases in the analysed samples. In the same way, the Cape Verde carbonatites show significant variations, especially for $\mathrm{CaO}\left(48.82-54.76\right.$ wt.\%), $\mathrm{SiO}_{2}\left(0.27-5.81\right.$ wt.\%), $\mathrm{P}_{2} \mathrm{O}_{5}(0.21-8.94$ wt.\%), and LOI (29.26-42.33 wt.\%) (Table A1).

The interpretation of trace element variations in carbonatites might be difficult due to several processes occurring in the route to the surface that could mask the pristine source and the primary processes (liquid immiscibility, crystal fractionation, occurrence of exotic accessory minerals high in incompatible elements), or the source region (e.g., the lack of well-constrained partition coefficients for trace elements between the peridotite or eclogite and carbonatite melts at high pressures, between $3 \mathrm{GPa}$ and $5 \mathrm{GPa}$, where carbonated source melting is likely to take place [75]), in addition to other parameters that may control trace element partitioning, the volatile content, and the occurrence of a mixed volatile free-fluid phase, oxygen fugacity, etc.

The large variation in incompatible elements and trace elements of oceanic carbonatites reflects the presence of different mineral phases such as pyrochlore (high in high-fieldstrength elements, HFSE, such as $\mathrm{Ta}, \mathrm{Nb}, \mathrm{Zr}$, Ti, Hf, and LREE), apatite (high in LREE, $\mathrm{Sr}$, Th, and $\mathrm{U}$ ), zircon (HFSE-rich), and titanite (HFSE-rich). Negative anomalies of $\mathrm{Zr}, \mathrm{Hf}$, and Ti are present, and this is typical of a carbonatite (or $\mathrm{CO}_{2}$-rich silicate melt metasomatized) in the garnet-peridotite stability field [76]. These negative anomalies are coupled to enrichment in REE and $\mathrm{Sr}$, and this is one of the main characteristics of carbonatite rocks. Consequently, mineral such as calcite and apatite are particularly enriched in Sr [77].

Representative multi-element (spider diagram) and REE patterns of both oceanic carbonatites are shown in Figure 3.

Fuerteventura and Cape Verde oceanic carbonatites show large variations in the abundances of most trace elements. High-field-strength elements (HFSE), large ion lithophile elements (LILE), such as $\mathrm{Rb}, \mathrm{Ba}, \mathrm{Pb}$, and $\mathrm{Sr}$, and $\mathrm{REE}$, range from 600-700 times below and above primitive mantle values (Figure 3a). All samples show fractionated REE patterns with high LREE with respect to HREE (a common feature of both continental and oceanic carbonatites), with moderate steep patterns $(\mathrm{La} / \mathrm{Yb})_{\mathrm{N}}=11-49$ (Figure $\left.3 b\right)$. The REE diagram shows also moderate negative Eu anomalies $\left(\mathrm{Eu} / \mathrm{Eu}^{*}=0.99-0.88\right)$, with some exception for some Fuerteventura $\left(\mathrm{Eu} / \mathrm{Eu}^{*}=1.02\right)$ and Cape Verde carbonatites $\left(\mathrm{Eu} / \mathrm{Eu}^{*}=1.03-1.09\right)$, coupled with large Sr positive anomalies $\left(\mathrm{Sr} / \mathrm{Sr}^{*}=9.6-28\right)$. Trace element variation of apatite in oceanic carbonatites (Table A2), with respect to whole-rock samples, suggests that the trace element budget and variability are mostly controlled by apatite (and other REE mineral reservoirs such as pyrochlore). It is worthy of note that calcite and apatite share broadly similar REE patterns (Figure 4), indicating that these mineral phases have a common origin and a genetic relationship in the magma from which they crystallized. On the contrary, clinopyroxene depicts different REE patterns if compared with calcite and apatite (Figure 4). 


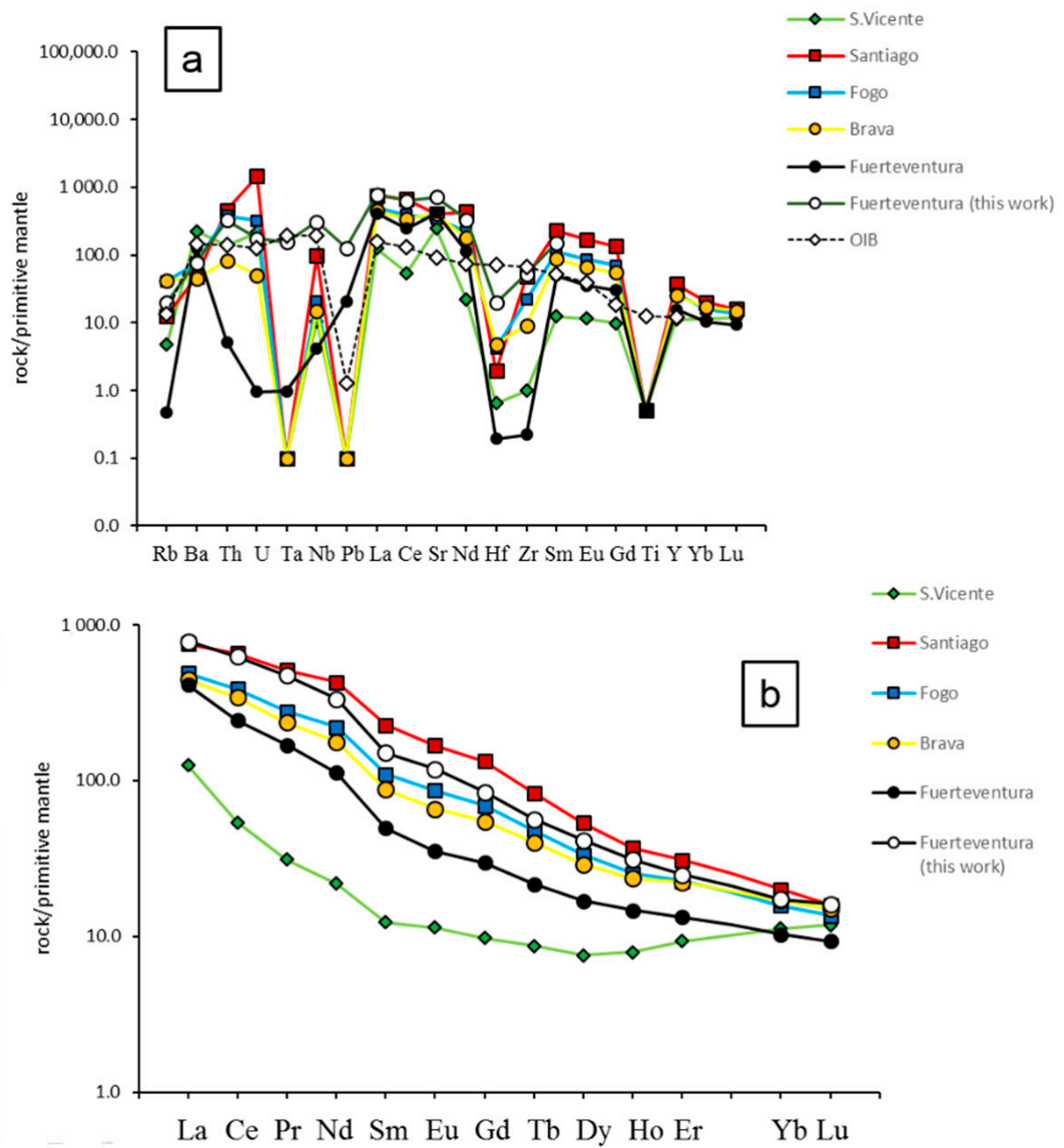

Figure 3. (a) Multi-element and (b) REE abundance diagram normalized to the primitive mantle of McDonough and Sun 1995 [78], showing patterns of representative samples of Fuerteventura and Cape Verde carbonatites (from Hoernle et al. 2002 and Doucelance et al. 2010, respectively [12,20]). Ocean island basalt (OIB) from Sun and McDonough 1989 [79].

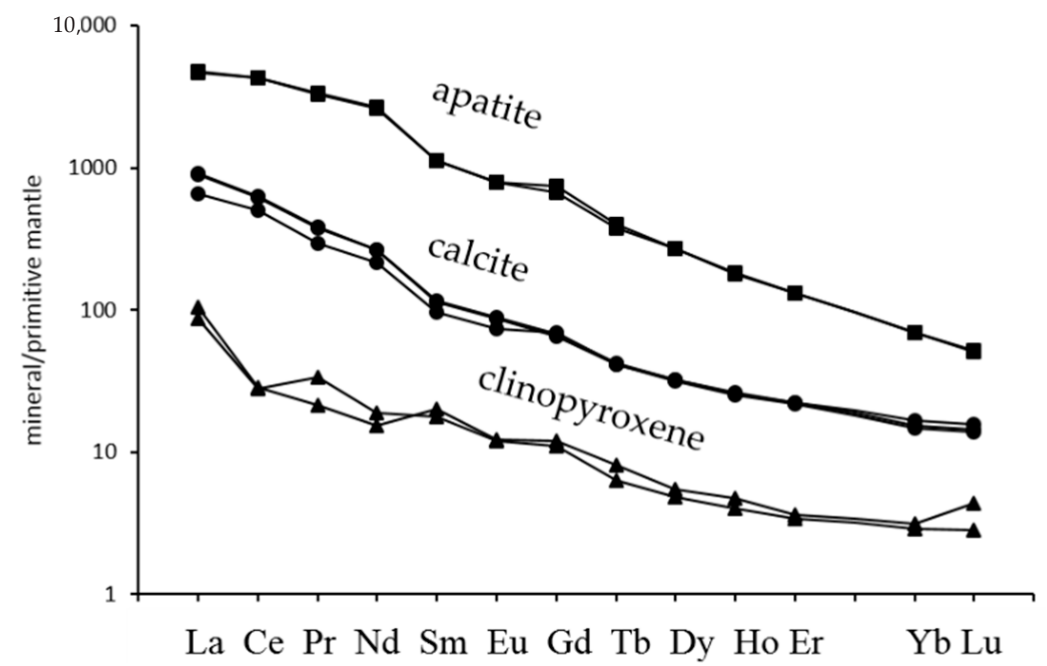

Figure 4. REE abundance diagram normalized to the primitive mantle of McDonough and Sun 1995 [78], showing patterns of apatite, calcite, and clinopyroxene on Fuerteventura carbonatites. 
A strong difference in $\mathrm{Cr}$ and $\mathrm{Ni}$ abundances in Fuerteventura samples between clinopyroxenes from carbonatite $(\mathrm{Cr}=13-17 \mathrm{ppm}, \mathrm{Ni}=8-13 \mathrm{ppm})$ and clinopyroxenes from clinopyroxenite $(\mathrm{Cr}=248-860 \mathrm{ppm}, \mathrm{Ni}=215-300 \mathrm{ppm})$ suggests that clinopyroxenes from clinopyroxenite crystallized from a primitive magma, while clinopyroxenes from carbonatite crystallized from an evolved magma. Indeed, Fuerteventura and Cape Verde oceanic carbonatites are both characterized by the presence of aegirine-augite, a clinopyroxene that crystallized from evolved magma [80].

Trace element data (this work) not only show a broadly similar trend in multi-element and REE abundance diagrams with previous Fuerteventura whole-rock carbonatites data [20], but also show a similar trend with Cape Verde carbonatites. Thus, both Fuerteventura and Cape Verde carbonatites depict the same trace element characteristics, almost tracing the same patterns in multi-element and REE abundance diagrams.

\subsubsection{Igneous vs. Hydrothermal Apatite}

Very commonly, the original mineral association of carbonatites is partially overprinted by late-stage metasomatic fluids [81], which precipitate phosphate minerals such as apatite-group, monazite or xenotime. Among these, apatite plays a dual role, being one of the earliest minerals in carbonatitic liquidus, but also a common late-stage metasomatic mineral.

The criteria we used to clarify apatite crystallization (near-liquidus or sub-solidus phase) were textural and chemical. We used a variety of chemical criteria typical of igneous carbonatites defined by Chakhmouradian et al. (2017) [82], such as concentrations of $\mathrm{Mn} \leq 1000 \mathrm{ppm}$ and $\mathrm{Sr} \geq 2000 \mathrm{ppm}, \delta \mathrm{Eu} \approx 1$ with $\delta \mathrm{Eu}=\mathrm{Eu}_{\mathrm{cn}} /\left[0.5 \times\left(\mathrm{Sm}_{\mathrm{cn}}+\right.\right.$ $\left.\left.\mathrm{Gd}_{\mathrm{cn}}\right)\right], 0.6 \leq \delta \mathrm{Y} \leq 0.9$ with $\delta \mathrm{Y}=\mathrm{Y}_{\mathrm{cn}} /\left[\left(0.25 \times \mathrm{Dy}_{\mathrm{cn}}\right)+\left(0.75 \times \mathrm{Ho}_{\mathrm{cn}}\right)\right]$, and $\delta \mathrm{Ce}>1$ with $\delta \mathrm{Ce}=\mathrm{Ce}_{\mathrm{cn}} /\left[0.5 \times\left(\mathrm{La}_{\mathrm{cn}}+\mathrm{Pr}_{\mathrm{cn}}\right)\right]$. Figure 5 a shows analysis of apatites from Fuerteventura carbonatites plotted on $\delta \mathrm{Eu}$ vs. $\delta \mathrm{Y}$ diagrams with different igneous and hydrothermal apatite fields. Almost all the analyses fall into the igneous apatite field, with $\delta$ Eu ranging from 0.82 to 0.91 and $\delta Y$ from 0.77 to 0.88 (see Table A3 for all plotted analyses), with some exception regarding only the $\delta \mathrm{Ce}$ criterion $(\delta \mathrm{Ce}<1)$. Mn and $\mathrm{Sr}$ concentrations are also in agreement with igneous origin (i.e., $\mathrm{Mn} \leq 1000 \mathrm{ppm}, \mathrm{Sr} \geq 2000 \mathrm{ppm}$ ). Apatites from Cape Verde carbonatites are not plotted on $\delta$ Eu vs. $\delta Y$ diagrams due to a lack of data.

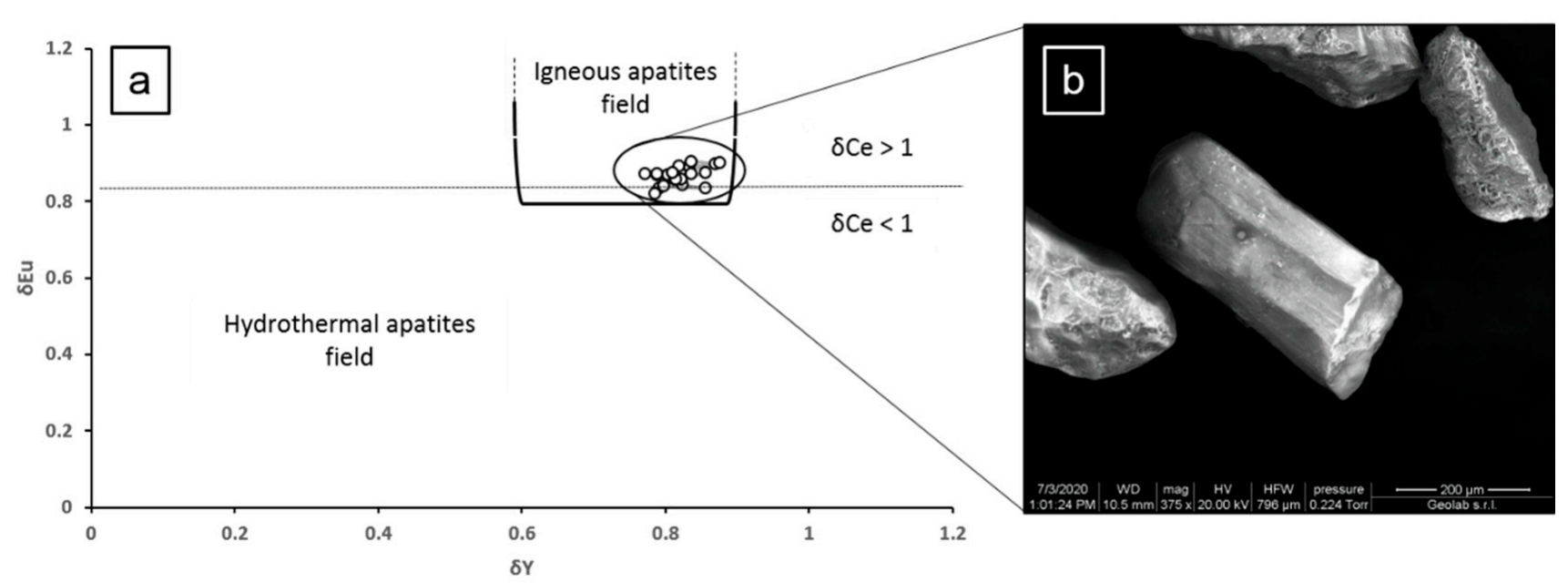

Figure 5. (a) Apatite minerals from Fuerteventura carbonatites plotted on $\delta$ Eu vs. $\delta Y$ diagrams with different igneous and hydrothermal apatite fields using REE criteria $(\delta \mathrm{Eu}, \delta \mathrm{Y}$, and $\delta \mathrm{Ce})$ of Chakhmouradian et al. 2017 [82]. (b) Secondary electron (SE) image of some plotted apatite minerals with a typical igneous tapered pill-like shape; scale bar $=200 \mu \mathrm{m}$.

In extrusive or shallow intrusive carbonatites, apatite occurs as euhedral prismatic phenocrysts and/or groundmass crystals [82]. On the contrary, igneous apatite from plutonic carbonatites normally occurs with smooth contours and a tapered pill-like shape [82], 
and apatite from Fuerteventura carbonatites presents this typical well-faceted morphology (Figure 5b), confirming its igneous origin.

Overall, trace elements and REE in apatites from Fuerteventura carbonatites are consistent with an igneous origin with a low/null interaction with metasomatic fluids instead of hydrothermal, allowing the choice of using apatite as a tracer for primary carbonatitic magma.

\subsection{Stable Isotopes $\left(\delta^{13} \mathrm{C}\right.$ and $\left.\delta^{18} \mathrm{O}\right)$}

Carbon and oxygen isotopic compositions of carbonates provide important information about the origin of the carbonatitic magma and the isotopic composition of the mantle source. The $\mathrm{C}$ and $\mathrm{O}$ isotopic compositions of the carbonatite compositional field, the so-called "primary igneous carbonatite" box, range between $6 \%$ and $10 \%$ for $\delta^{18} \mathrm{O}$ (SMOW) and between $-4 \%$ and $-8 \%$ for $\delta^{13} \mathrm{C}$ (PDB) [83-85]. Recent work on Oldoinyo Lengai (the only worldwide active volcano that erupts Na-carbonatitic magma) volcanic fresh products allowed us to narrow the range of the $\mathrm{C}$ and $\mathrm{O}$ isotopic signature of primary igneous carbonatites, and, although particular as natrocarbonatites, the range can be considered representative of undegassed and uncontaminated mantle compositions, with $\delta^{13} \mathrm{C}$ values ranging from $-5 \%$ to $-7 \%$ and $\delta^{18} \mathrm{O}$ values ranging from $5.5 \%$ to $7 \%$ [ [86].

Compared with the mantle range for oxygen isotopes, the carbon isotope signature of the mantle is more difficult to constrain due to the apparent under-estimation of hightemperature fractionation for carbon in the mantle [87] and also because the average concentration of the carbon in the mantle is still uncertain [88-90]. Thus, even though C and $\mathrm{O}$ isotope compositions give important information regarding carbonatite genesis, there are several secondary processes that may affect the primary mantle fingerprint, such as low-temperature alteration, high-temperature fractionation or crustal assimilation, causing post-emplacement changes in $\delta^{13} \mathrm{C}$ and $/$ or $\delta^{18} \mathrm{O}$ values [91,92], and making their interpretation particularly difficult.

Figure 6 shows oxygen and carbon isotope compositions for Fuerteventura and Cape Verde carbonatites, plotted within the mantle boxes of Taylor et al. (1967) and Keller and Hoefs (1995) [83,86]. The $\delta^{13} \mathrm{C}$ values of calcite in Fuerteventura carbonatites are within the primary igneous carbonatite field as originally defined by Taylor et al. (1967) [83], but also in the smaller range proposed by later authors [86], with $\delta^{13} \mathrm{C}$ values ranging from $-5 \%$ to $-7 \%$ [11]. Oxygen isotope compositions of Fuerteventura carbonatites vary in a slightly wider range if compared with carbon isotope compositions $\left(\delta^{18} \mathrm{O}\right.$ values ranging from $5.2 \%$ to $9.6 \%$ ), and this is related to local fluid/rock interactions, as a result of low-temperature isotopic exchange between carbonatites and water-rich fluids where $\delta^{13} \mathrm{C}$ is not affected [11].

Typical mantle $\delta^{13} \mathrm{C}$ values ( $-8 \%$ o to $-4.2 \%$ ) were measured in Cape Verde carbonatites [23], suggesting a role of primordial carbon in their genesis. In contrast, $\delta^{13} \mathrm{C}(-0.6 \%$ to $-0.2 \%$ ) and $\delta^{18} \mathrm{O}(12.3 \%$ to $21 \%$ ) values obtained for dolomite separates from Cape Verde Mg-rich carbonatites show clearly atypical mantle-derived values, suggesting the contribution of secondary processes to the carbon and oxygen isotopic signature [20,23].

Overall, carbon and oxygen isotope compositions of both oceanic carbonatites (Fuerteventura and Cape Verde) share a common mantle-derived isotopic signature, with the exception of Mg-carbonatites from Cape Verde, in which secondary processes are more evident. 


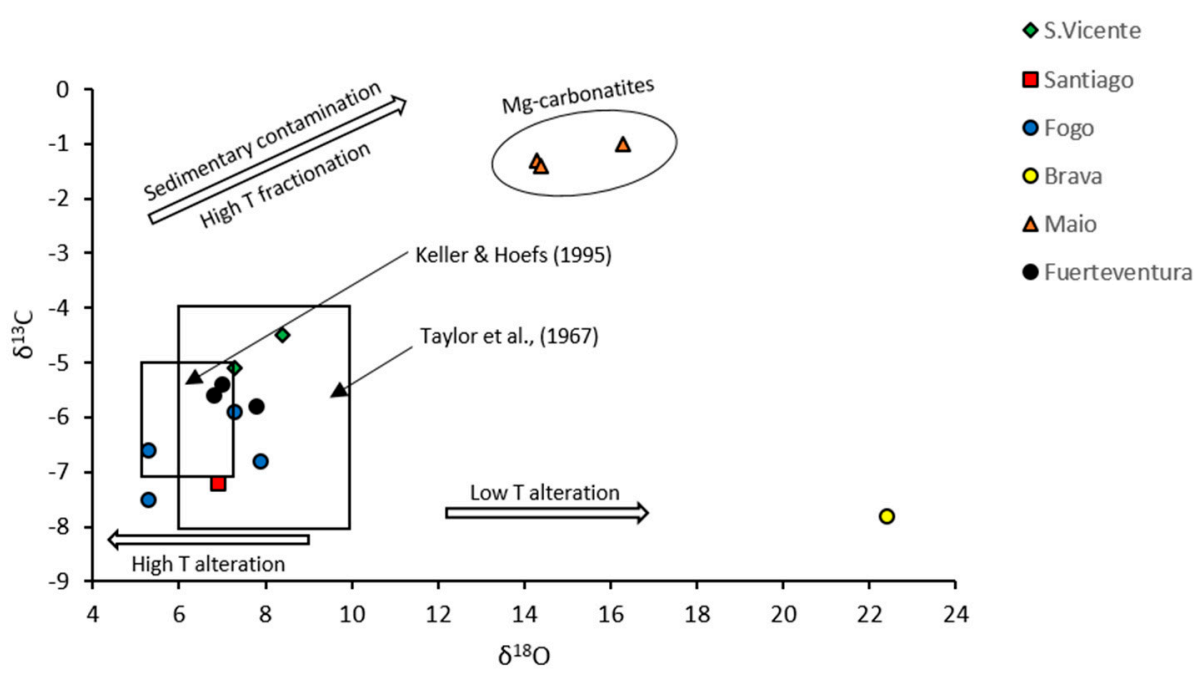

Figure 6. Stable isotope $\left(\delta^{13} \mathrm{C}\right.$ and $\left.\delta^{18} \mathrm{O}\right)$ compositions (in \%o relative to PDB and SMOW, respectively) of Fuerteventura and Cape Verde carbonatites. White arrows indicate possible post-emplacement changes in $\delta^{13} \mathrm{C}$ and/or $\delta^{18} \mathrm{O}$ values caused by secondary processes. Data from Hoernle et al. 2002 [20].

\subsection{Sr-Nd-Pb Isotopic Systematics}

Radiogenic Sr-Nd-Pb isotopic systematics have been widely used to characterize the sources of the oceanic carbonatites and the contribution of the different end members involved in carbonatites genesis. De Ignacio et al. (2006) proposed a FOZO (defined as a source region deep-seated in the mantle by Hart et al. 1992 [93]) mixed with HIMU ("high $\mu^{\prime \prime}, \mu={ }^{238} \mathrm{U} /{ }^{204} \mathrm{~Pb}$ ratio) signature for alkali-carbonatitic association of Fuerteventura [21]. However, the involvement of a FOZO mantle component in the carbonatite source is difficult to be exactly constrained. Indeed, many $\mathrm{Sr}-\mathrm{Nd}$ isotopic ratios of carbonatites plot into the FOZO field [94], and if we consider the more recent definitions of the FOZO component $[95,96]$, most of those Ca-carbonatites plot outside of the box (Figure 9a in Doucelance et al. 2010 [12].

Sr initial isotopic ratios (calculated for an age of $25 \mathrm{Ma}$ [21]) of Fuerteventura carbonatites plot in a very restricted range $\left(0.703202 \leq\left({ }^{87} \mathrm{Sr} /{ }^{86} \mathrm{Sr}\right)_{\mathrm{i}} \leq 0.703244\right)$, similar to the $\mathrm{Nd}$ initial isotopic ratios $\left(0.512840 \leq\left({ }^{143} \mathrm{Nd} /{ }^{144} \mathrm{Nd}\right)_{\mathrm{i}} \leq 0.512877\right)$ [21]. The restricted range of Sr isotopic ratios of Fuerteventura carbonatites is clearly at odds with a large degree of assimilation of sedimentary carbonate proposed by Demény et al. (1998) [11]. If we assume $10 \%$ to $20 \%$ assimilation of sedimentary carbonate during differentiation processes in shallow magma chambers in the alkaline-carbonatitic complex of Fuerteventura [11], Sr isotopic ratios would not plot in such a narrow range, as evidenced by De Ignacio et al. (2006) [21].

Even though both Fuerteventura and Cape Verde oceanic carbonatites have similar isotopic compositions, Fuerteventura carbonatites show some differences with respect to the Cape Verde compositions. If we compare the previous $\mathrm{Sr}$ and $\mathrm{Nd}$ initial isotopic ratios of Fuerteventura with Cape Verde carbonatites, the latter show a slightly wider range. Indeed, the $\left({ }^{87} \mathrm{Sr} /{ }^{86} \mathrm{Sr}\right)_{\mathrm{i}}$ ratio varies from 0.703120 (S. Vicente, northern Archipelago) to 0.703356 (Brava, southern Archipelago), and the $\left({ }^{143} \mathrm{Nd} /{ }^{144} \mathrm{Nd}\right)_{i}$ ratio varies from 0.512884 to 0.512911 , for S. Vicente and Brava, respectively [12]. Regarding lead isotopic ratios, Fuerteventura displays lower ${ }^{206} \mathrm{~Pb} /{ }^{204} \mathrm{~Pb}$ and ${ }^{207} \mathrm{~Pb} /{ }^{204} \mathrm{~Pb}$ and slightly higher ${ }^{208} \mathrm{~Pb} /{ }^{204} \mathrm{~Pb}$ ratios if compared with the other oceanic carbonatites [21], being in the range from 19.601 to 19.869 for the ${ }^{206} \mathrm{~Pb} /{ }^{204} \mathrm{~Pb}$ ratio, from 15.593 to 15.602 for the ${ }^{207} \mathrm{~Pb} /{ }^{204} \mathrm{~Pb}$ ratio, and from 39.536 to 39.672 for ${ }^{208} \mathrm{~Pb} /{ }^{204} \mathrm{~Pb}$ [21]. Cape Verde carbonatites instead plot in a large range on the uranogenic $\mathrm{Pb}$ isotope diagram, varying from 19.646 to 20.338 for the ${ }^{206} \mathrm{~Pb} /{ }^{204} \mathrm{~Pb}$ ratio and from 15.586 to 15.657 for the ${ }^{207} \mathrm{~Pb} /{ }^{204} \mathrm{~Pb}$ ratio [21]. 
Although it is more evident considering Cape Verde basaltic rocks, the slightly wider range of $\mathrm{Sr}-\mathrm{Nd}-\mathrm{Pb}$ isotopes in Cape Verde carbonatites is probably due to the isotopic dichotomy of the Cape Verde Archipelago, involving a depleted end-member mostly evident in northern Islands (interpreted as the local oceanic lithosphere assimilated by ascending plume melts [97]) and an enriched end-member (compatible with old marine carbonates) with an EMI-like ("enriched mantle I") isotopic signature predominant in the southern Islands [12].

Figure 7 compares $\mathrm{Sr}-\mathrm{Pb}$ and $\mathrm{Nd}-\mathrm{Pb}$ ratios of Fuerteventura and Cape Verde carbonatites, and isotope diagrams show a more restricted range for Fuerteventura carbonatites compared to Cape Verde carbonatites. Interestingly, even though both oceanic carbonatites present slight isotopic differences, Fuerteventura and Cape Verde carbonatites project in the middle of the field defined by the three end-member mantle components: DMM, EM-I (especially the southern Cape Verde Islands), and HIMU, being similar to the Canary and Cape Verde mafic rocks (Figure 7a,b).

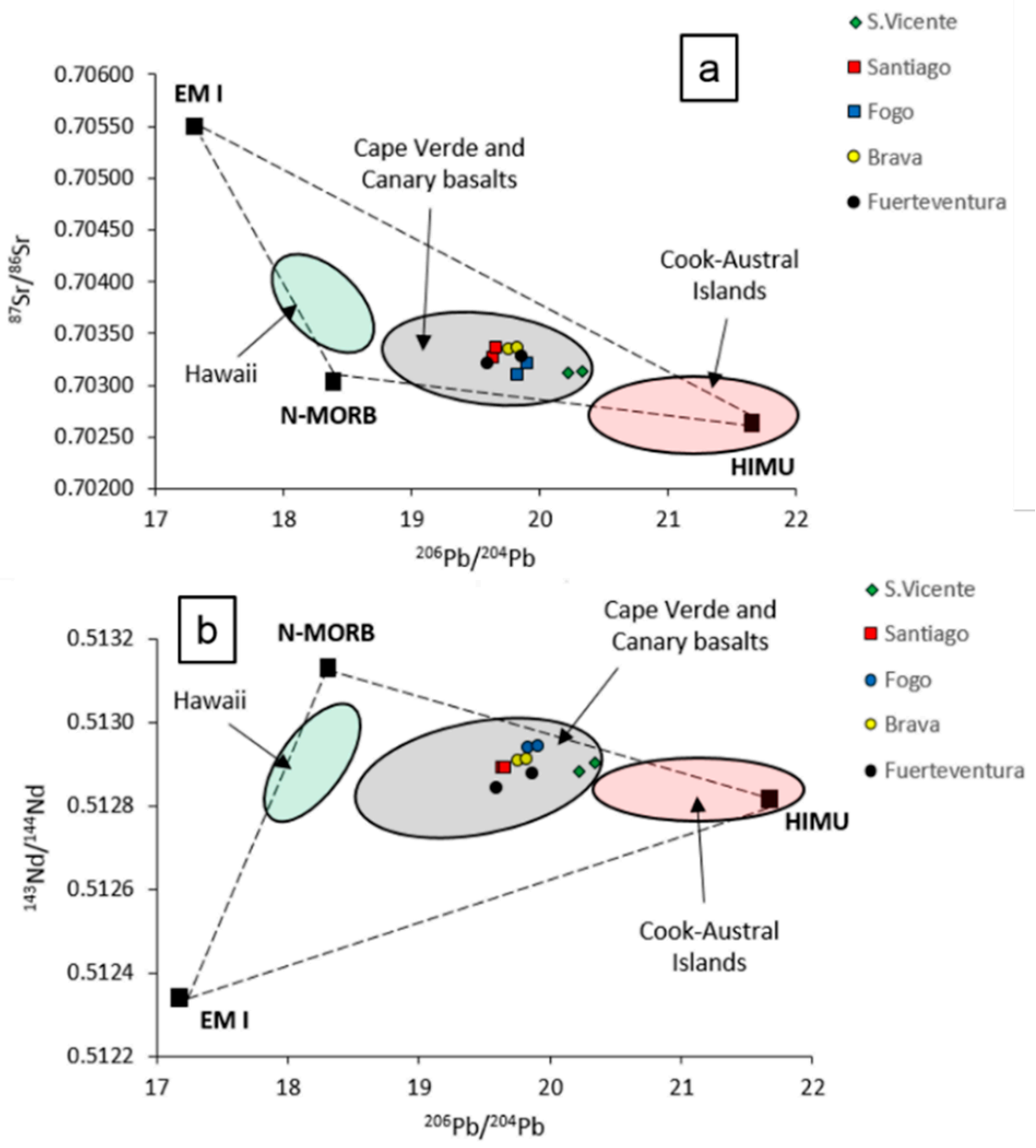

Figure 7. (a) ${ }^{87} \mathrm{Sr} /{ }^{86} \mathrm{Sr}$ vs. ${ }^{206} \mathrm{~Pb} /{ }^{204} \mathrm{~Pb}$ and (b) ${ }^{143} \mathrm{Nd} /{ }^{144} \mathrm{Nd}$ vs. ${ }^{206} \mathrm{~Pb} /{ }^{204} \mathrm{~Pb}$ initial ratios of Fuerteventura and Cape Verde carbonatites (data from De Ignacio et al. 2006 and Hoernle et al. 2002, respectively [20,21]). Mantle components after Hart (1988) [98]. Also shown for comparison are the following: (1) Canary and Cape Verde basalts [99,100]; (2) Hawaii [101-103] and Cook-Austral Islands volcanic rocks [95].

The Canary and Cape Verde basalts and carbonatites clearly differ from HIMU-OIB and OIB isotopic compositions represented by Cook-Austral Islands and Hawaii, suggesting a different geochemical footprint and just a slight contribution of a moderately radiogenic $\mathrm{Pb}$ isotope signature, comparable with isotopic compositions of the second group of OIB defined by Stracke et al. (2005) [95], with ${ }^{206} \mathrm{~Pb} /{ }^{204} \mathrm{~Pb}=19.5-20.5$. Overall, 
Canary (Fuerteventura) and Cape Verde carbonatites, regarding Sr-Nd-Pb isotopic compositions, appear to be generated from a binary mixing between the DMM component and a secondary component resulting from a mixing involving an enriched mantle component (EM-I) and a moderate HIMU-like component, reflecting a similar trend on $\mathrm{Sr}-\mathrm{Pb}$ and $\mathrm{Nd}-\mathrm{Pb}$ diagrams. Previous studies of the mantle source on Cape Verde magmas show the DMM component as dominant in the northern Cape Verde islands and in lesser amounts in the sub-continental lithospheric mantle (SCLM) component relative to those of the southern Islands $[100,104]$. Furthermore, the occurrence of a delaminated sub-continental lithospheric mantle domain beneath the southern Cape Verde Islands was also proposed [105,106], considering Cape Verde carbonatites derived from the melting of such a SCLM domain. On the contrary, Mata et al. (2010) [23], given the high ${ }^{3} \mathrm{He} /{ }^{4} \mathrm{He}$ ratios in calcite and apatite minerals of Cape Verde carbonatites ( $\mathrm{R} / \mathrm{Ra}$ up to 15.5), exclude the SCLM domain as their origin, considering the high ${ }^{3} \mathrm{He} /{ }^{4} \mathrm{He}$ ratios as evidence of a deep mantle contribution to the carbonatite genesis. The role of the primitive high He signature as a component on the Cape Verde carbonatites genesis and its relationship with the He signature of Fuerteventura carbonatites will be discussed in detail in the Section 5.4.2.

\subsection{Noble Gas (He, Ne, Ar) Isotopes}

\subsubsection{Radiogenic Time-Integrated ${ }^{4} \mathrm{He}{ }^{*}$ Production}

Apatite samples from Fuerteventura carbonatites (FUE1-03 and FUE1-04) present a radiogenic ${ }^{4} \mathrm{He}^{*}$ content of approximately $7 \times 10^{-6} \mathrm{ccSTP} / \mathrm{g}$ (Table 4 ), compared with a measured ${ }^{4} \mathrm{He}$ content of a few $10^{-7} \mathrm{ccSTP} / \mathrm{g}$ (221 and 51.6 for FUE1-03 and FUE1-04, respectively). Thus, the low percentage of the radiogenic ${ }^{4} \mathrm{He}^{*}$ is high enough to dominate the signal of the mantle-derived He. The radiogenic ${ }^{4} \mathrm{He}^{*}$ production on apatite separates from Cape Verde carbonatites (Table A4), although they present lower Th and U contents than Fuerteventura carbonatites (up to $133 \mathrm{ppm}$ for Th and $15 \mathrm{ppm}$ for $\mathrm{U}$ ), is also high enough to influence the apatite He signal [23].

With respect to apatite, calcite contains significantly lower Th and U contents (up to 8.6 ppm and 1.4 ppm, respectively) (Table 4), and therefore the radiogenic ${ }^{4} \mathrm{He}^{*}$ contribution to decrease the pristine He isotopic signature is lower than in apatite. Clinopyroxene from carbonatites and clinopyroxenite also presents low Th and U contents (Table 4). In the same way, calcite separates from Cape Verde carbonatites present low Th and U contents (up to $20.4 \mathrm{ppm}$ and $2.7 \mathrm{ppm}$, respectively), less affecting their pristine isotopic signature.

Overall, given the modal abundance of apatite of Fuerteventura and Cape Verde carbonatites and their magmatic origin, due to the high contents of Th and $\mathrm{U}$, they are not good indicators of the noble gas isotopic signature of their precursor magmas. On the contrary, calcite and clinopyroxene are good tracers for the magma source and its $\mathrm{He}$ isotopic signature.

\subsubsection{R/Ra: Shallow vs. Deep Primitive He Isotopic Signature}

Even though the calcite ${ }^{3} \mathrm{He} /{ }^{4} \mathrm{He}$ ratios of Fuerteventura carbonatites (up to 3.86Ra) are a little higher than clinopyroxenes $(\approx 2.23 \mathrm{Ra}$ ) and higher than apatites (up to $0.08 \mathrm{Ra}$ ) within the carbonatite, they present values significantly lower than typical MORB mantle values $\left(\mathrm{R} / \mathrm{Ra}=8 \pm 1\right.$ ) [107], while clinopyroxenes from clinopyroxenite show ${ }^{3} \mathrm{He} /{ }^{4} \mathrm{He}$ ratios $(\approx 6.66 \mathrm{Ra})$ slightly lower than typical MORB mantle values and in the range of sub-continental lithospheric mantle values (SCLM, 6.1 Ra \pm 0.9 [108]). In contrast, calcite and apatite ${ }^{3} \mathrm{He} /{ }^{4} \mathrm{He}$ ratios of Cape Verde carbonatites present values higher than typical MORB mantle values, reaching values of $15.5 \mathrm{Ra}$ and 9.76Ra, respectively (Table A5).

The lower R/Ra values for mineral separates from Fuerteventura carbonatites might be caused by "magma aging" (i.e., internal production of radiogenic ${ }^{4} \mathrm{He}^{*}$ from $\mathrm{U}$ and Th contents that lower the original $\mathrm{R} / \mathrm{Ra}$ ratio of the magmatic source). However, considering (i) ${ }^{3} \mathrm{He}$ and ${ }^{4} \mathrm{He}$ concentration, (ii) Th and $\mathrm{U}$ contents measured in calcite and clinopyroxene separates, and (iii) contributions of radiogenic ${ }^{4} \mathrm{He}^{*}$ (see Table 4 for radiogenic 
${ }^{4} \mathrm{He}^{*}$ calculation), using a simple magma aging model, initial $\mathrm{R} / \mathrm{Ra}$ ratios of calcite and clinopyroxene from carbonatite and clinopyroxene from clinopyroxenite are not significantly modified. Indeed, initial $\mathrm{R} / \mathrm{Ra}$ ratios continue to present values lower than typical MORB mantle values $(\approx 5.10 \mathrm{Ra}$ and $\approx 5.24 \mathrm{Ra}$ for calcite and clinopyroxene from carbonatite and $\approx 6.82 \mathrm{Ra}$ for clinopyroxene from clinopyroxenite), and they are in the SCLM range. An age of 53.5 Ma would be required for Fuerteventura carbonatites to result in the initial $\mathrm{R} /$ Ra ratio of 8 for calcite, and this is not realistic with their ages of about $25 \mathrm{Ma}$ [43]. We therefore consider the He isotopic ratio from the calcite to be reflective of a sub-continental lithospheric mantle signature.

If plotted onto R/Ra vs. ${ }^{4} \mathrm{He} /{ }^{20} \mathrm{Ne}$ ratios diagrams (Figure 8a), calcite samples from Fuerteventura carbonatites fall below the SCLM field, and they clearly differ from those of Cape Verde carbonatites that fall between the MORB field and plume-type field.
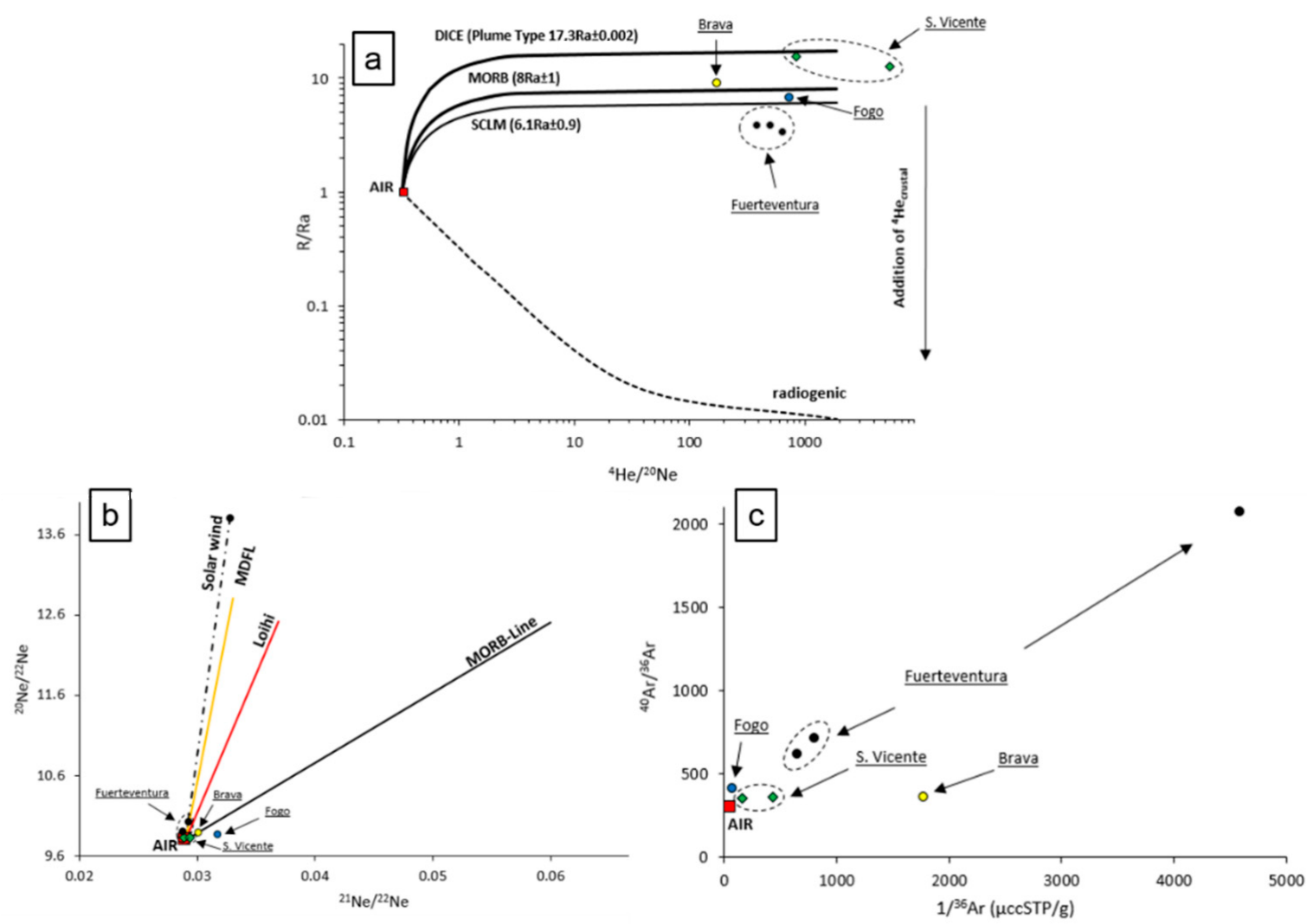

Figure 8. (a) R/Ra ratios vs. ${ }^{4} \mathrm{He} /{ }^{20} \mathrm{Ne}$ ratios obtained by crushing calcite in Fuerteventura and Cape Verde carbonatites. (b) ${ }^{20} \mathrm{Ne} /{ }^{22} \mathrm{Ne}$ vs. ${ }^{21} \mathrm{Ne} /{ }^{22} \mathrm{Ne}$ and (c) ${ }^{40} \mathrm{Ar} /{ }^{36} \mathrm{Ar}$ vs $1 /{ }^{36} \mathrm{Ar}$ diagram from the same samples. Data from the Cape Verde islands are from Mata et al. 2010 [23]. Mixing lines in the ${ }^{20} \mathrm{Ne} /{ }^{22} \mathrm{Ne}$ vs ${ }^{21} \mathrm{Ne} /{ }^{22} \mathrm{Ne}$ diagram are from Broadley et al. 2020 [109]. The ${ }^{20} \mathrm{Ne} /{ }^{22} \mathrm{Ne}$ and ${ }^{21} \mathrm{Ne} /{ }^{22} \mathrm{Ne}$ air ratio is taken from Ozima and Podosek, 2002 [73], while the ${ }^{40} \mathrm{Ar} /{ }^{36} \mathrm{Ar}$ air ratio is taken from Lee et al. 2006 [74].

The ${ }^{20} \mathrm{Ne} /{ }^{22} \mathrm{Ne}$ and ${ }^{21} \mathrm{Ne} /{ }^{22} \mathrm{Ne}$ ratios of calcite from Fuerteventura carbonatites are not distinguishable from the value of the air and from the mass-dependent fractionation line (MDFL), while calcites from Cape Verde carbonatites seem to plot along the mixing line between air and the hypothetical pristine MORB value, with the exception of Fogo Island (Figure $8 b$ ). On the contrary, ${ }^{20} \mathrm{Ne} /{ }^{22} \mathrm{Ne}$ and ${ }^{21} \mathrm{Ne} /{ }^{22} \mathrm{Ne}$ ratios of apatite from Cape Verde carbonatites, in which the values are distinct from air ratios, plot clearly to the left of the MORB line (Figure 3 in Mata et al. 2010 [23]).

Furthermore, Fuerteventura carbonatites show higher ${ }^{40} \mathrm{Ar} /{ }^{36} \mathrm{Ar}$ isotopic ratios than Cape Verde carbonatites (Figure 8c), suggesting a lower extent of atmospheric contamination.

Figure 9 shows a summary of the proposed mantle components for Canary and Cape Verde primitive magmas and shows a clear regional distribution and an isotopic dichotomy 
of ${ }^{3} \mathrm{He} /{ }^{4} \mathrm{He}$ ratios in both silicate rocks and Cape Verde carbonatites. Samples from the northern Cape Verde Islands (e.g., S. Antão, S. Vicente, and S. Nicolau) present a relatively primitive He signature, indicating the involvement of the relatively primordial mantle component in these magmas, while samples from the southern Cape Verde Islands (e.g., Fogo and Santiago) present MORB-like values [23,100]. This regional distribution appears to be slight on the Canary Islands, with an apparent increase in R/Ra from eastern (oldest) to western (youngest) islands, and all islands with the exception of Fuerteventura present MORB-like values (Figure 9). Interestingly, both Fuerteventura carbonatites and silicate rocks present $\mathrm{R} / \mathrm{Ra}$ values lower to slightly lower than typical MORB mantle values, and they are in the SCLM range.

A recent study on helium isotope variations in geothermal fluids of the Canary Islands [110] shows the presence of distinct He reservoirs, with a moderately radiogenic lead-rich mantle source for La Palma (western Canaries) and a more enriched mantle source with the possible involvement of a continental lithospheric mantle influence for Tenerife (central Canaries). These authors show how the differences in ${ }^{3} \mathrm{He} /{ }^{4} \mathrm{He}$ ratios between La Palma and Tenerife are not evident if we consider the values from mineral separates (La Palma = 9.7-6.6Ra; Tenerife $=8.6-6.6 \mathrm{Ra}$ ), which show considerable overlap (Figure 1 in Day and Hilton, 2020 [110]). On the contrary, the analysis of fluids and gases from geothermal systems of the same islands $(\mathrm{La}$ Palma $=9.27-8.79 \mathrm{Ra}$; Tenerife $=6.63-6.09 \mathrm{Ra})$ allow us to identify a heterogeneous mantle below the Canary Islands.

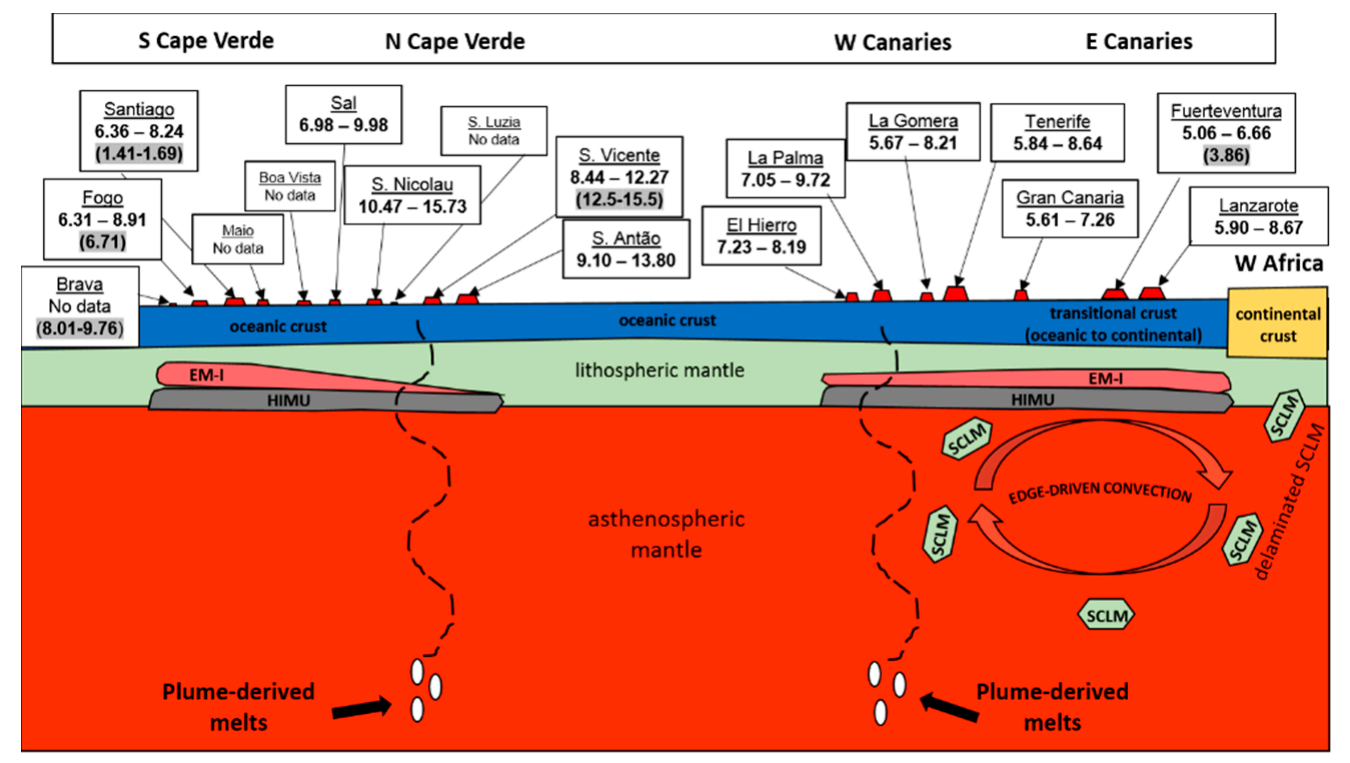

Figure 9. Hypothetical schematic profile view of the upper mantle/crust under the Cape Verde and Canary Archipelago (not to scale) with the involvement of the proposed mantle components and the mechanism of physical detachment of the sub-continental lithospheric mantle (SCLM) caused by edge-driven convection during breakup of the Pangea Supercontinent and incorporated into the oceanic lithospheric mantle beneath at least some Canary Islands [20,24,112,113]. Also shown is a geographical distribution of the $\mathrm{R} / \mathrm{Ra}$ range for each island of olivine (clinopyroxene in the case of Fuerteventura) from mafic/ultramafic rocks, and calcite from carbonatites (values in grey field). Data for the Canary Islands are from [99] for Gran Canaria, Tenerife and La Gomera; [111] for La Palma and El Hierro; [114] for Lanzarote. Data for the Cape Verde Archipelago are from [115] for S. Antão; [100] for Fogo, Santiago, S. Vicente, S. Nicolau and Sal; [23] for Fogo, Santiago, S. Vicente and Brava (on carbonatites).

To sum up, ${ }^{3} \mathrm{He} /{ }^{4} \mathrm{He}$ ratios in both silicate rocks and carbonatites from the northern Cape Verde Islands range from MORB-like values towards the high ${ }^{3} \mathrm{He} /{ }^{4} \mathrm{He}$ values that indicate a relatively primordial mantle signature, while ${ }^{3} \mathrm{He} /{ }^{4} \mathrm{He}$ ratios from the southern Cape Verde Islands and Canary Islands range from MORB-like values extending 
to lower values, revealing the involvement of a refertilized SCLM component in their source $[99,100,111]$. The He isotopic signature of Fuerteventura carbonatites clearly differs from the Cape Verde carbonatites, probably due to deep mantle plume-derived melts.

\section{Conclusions}

The comparison of our new data on trace elements in minerals and whole-rock and noble gas isotopes (He, $\mathrm{Ne}, \mathrm{Ar}$ ) of Fuerteventura carbonatites with literature data of Fuerteventura and Cape Verde oceanic carbonatites allow us to state the following points:

- Even though Fuerteventura and Cape Verde oceanic carbonatites show differences in some trace element abundances, their patterns in the multi-element and REE abundance diagrams are remarkably similar.

- Carbon and oxygen isotope $\left(\delta^{13} \mathrm{C}\right.$ and $\left.\delta^{18} \mathrm{O}\right)$ compositions of Fuerteventura and Cape Verde carbonatites share a common isotopic signature, showing typical mantle-derived values and plotting into the so-called "primary igneous carbonatite" box.

- $\quad$ Although they present slight differences in $\mathrm{Sr}-\mathrm{Nd}-\mathrm{Pb}$ isotopic compositions, Fuerteventura and Cape Verde carbonatites seem to reflect contributions from three mantle components (DMM, EM-I, and HIMU), particularly from a mixing between a MORB-like component and a second component resulting from an enriched mantle component and a moderately HIMU-like component, showing a similar trend in $\mathrm{Sr}-\mathrm{Pb}$ and $\mathrm{Nd}-\mathrm{Pb}$ diagrams.

- $\quad{ }^{3} \mathrm{He} /{ }^{4} \mathrm{He}$ ratios of Fuerteventura carbonatites and adjacent clinopyroxenite are in the range of sub-continental lithospheric mantle (SCLM) and they are different if compared with the He isotopic signature of Cape Verde carbonatites, in which a deep lower mantle contribution is present. Comparing major and trace elements and C-O$\mathrm{Sr}-\mathrm{Nd}-\mathrm{Pb}-\mathrm{He}-\mathrm{Ne}-\mathrm{Ar}$ isotopes of Fuerteventura and Cape Verde carbonatites, the only marked difference is represented by the He isotopic signature, with a shallow (subcontinental lithospheric mantle, SCLM) He signature for Fuerteventura carbonatites, and a deep (lower mantle) He signature for Cape Verde carbonatites.

Future research on the importance of the heterogeneous metasomatism of the oceanic lithosphere (carbonatites occur only on a few islands of the Canary and Cape Verde Archipelagos) and a possible role of the lithosphere thickness could be fundamental to understand why oceanic carbonatites are so rare and are not found in all HIMU-OIB-like archipelagos. As mantle reservoirs that possibly source carbonatite formation could be similar in some cases (plume-, MORB- or SCLM-), it would be reasonable to compare the mantle signature of noble gases in the studied oceanic carbonatites with intra-continental carbonatites. Furthermore, future research should be focused on obtaining stepwise crushing data for noble gases in order to better characterize all the non-magmatic isotopic component contributions in a large set of samples.

Author Contributions: Conceptualization, G.C., A.C. (Antonio Caracausi), A.C. (Alessandra Correale), S.G.R.; investigation, G.C.; methodology, G.C., A.C. (Antonio Caracausi) and S.G.R.; formal analysis, A.C. (Antonio Caracausi), A.C. (Alessandra Correale) and L.I; samples preparation, G.C. and L.I.; writing—original draft preparation, G.C.; supervision, A.C. (Antonio Caracausi) and S.G.R. All authors have read and agreed to the published version of the manuscript.

Funding: This research received no external funding.

Institutional Review Board Statement: Not applicable.

Informed Consent Statement: Not applicable.

Data Availability Statement: Data are contained within the article and Appendix A.

Acknowledgments: Authors are grateful to editors and three anonymous reviewers for their helpful and constructive reviews.

Conflicts of Interest: The authors declare no conflict of interest. 


\section{Appendix A}

Table A1. Literature data of major and trace element compositions of Fuerteventura and Cape Verde whole-rock carbonatites.

\begin{tabular}{|c|c|c|c|c|c|c|c|c|c|c|}
\hline \multirow{2}{*}{$\begin{array}{l}\text { Occurrence } \\
\text { Sample }\end{array}$} & \multicolumn{2}{|c|}{ Fuerteventura } & \multicolumn{2}{|c|}{ Brava } & \multicolumn{2}{|c|}{ Fogo } & \multicolumn{2}{|c|}{ Santiago } & \multicolumn{2}{|c|}{ S. Vicente } \\
\hline & $68 \mathrm{SC} / 73$ & F/75/65 & Br-15 & Br-23 & F-211C & F-230B & S-309 & S-311 & SV-186 & SV-188 \\
\hline $\begin{array}{c}\mathrm{SiO}_{2} \\
\text { (wt.\%) }\end{array}$ & 5.85 & 0.92 & 3.04 & 0.27 & 4.62 & 5.81 & 4.12 & 0.84 & 0.80 & 0.56 \\
\hline $\mathrm{TiO}_{2}$ & 0.34 & 0.02 & 0.21 & 0.00 & 0.29 & 0.09 & 0.47 & 0.08 & 0.03 & 0.03 \\
\hline $\mathrm{Al}_{2} \mathrm{O}_{3}$ & 3.24 & 0.35 & 0.52 & 0.10 & 1.02 & 1.44 & 0.35 & 0.11 & 0.18 & 0.08 \\
\hline $\mathrm{Fe}_{2} \mathrm{O}_{3 \mathrm{t}}$ & 6.20 & 0.36 & 3.93 & 2.16 & 3.54 & 1.87 & 4.67 & 2.64 & 1.20 & 1.10 \\
\hline $\mathrm{MnO}$ & 0.24 & 0.26 & 0.27 & 0.36 & 0.18 & 0.22 & 0.26 & 0.31 & 0.10 & 0.22 \\
\hline $\mathrm{MgO}$ & 0.96 & 0.11 & 0.45 & 0.12 & 1.05 & 0.57 & 1.89 & 0.38 & 0.58 & 0.67 \\
\hline $\mathrm{CaO}$ & 48.10 & 51.40 & 49.75 & 53.87 & 49.51 & 49.35 & 48.82 & 53.92 & 54.76 & 54.59 \\
\hline $\mathrm{Na}_{2} \mathrm{O}$ & 1.16 & 0.35 & 0.31 & 0.08 & 0.21 & 0.61 & 0.31 & 0.16 & 0.11 & 0.11 \\
\hline $\mathrm{K}_{2} \mathrm{O}$ & 0.10 & 0.02 & 0.26 & 0.05 & 0.42 & 0.28 & 0.13 & 0.08 & 0.18 & 0.09 \\
\hline $\mathrm{P}_{2} \mathrm{O}_{5}$ & 1.51 & 1.36 & 5.63 & 0.21 & 3.30 & 2.11 & 8.94 & 2.39 & 3.27 & 0.56 \\
\hline LOI & 31.50 & 42.60 & 34.20 & 42.33 & 35.93 & 36.78 & 29.26 & 39.56 & 39.39 & 42.00 \\
\hline Total & 99.20 & 97.75 & 98.57 & 99.55 & 100.07 & 99.13 & 99.22 & 100.47 & 100.60 & 100.01 \\
\hline Sr (ppm) & 8770 & 6900 & 8466 & 8622 & 7301 & 9222 & 8568 & 10,000 & 5146 & 6423 \\
\hline $\mathrm{Y}$ & 71.60 & 139 & 115 & 98.80 & 120 & 94.40 & 169 & 119 & 50.30 & 74.90 \\
\hline $\mathrm{Rb}$ & 0.30 & 0.30 & 27 & 1 & 26 & 8 & 8 & 5 & 3 & 1 \\
\hline $\mathrm{Ba}$ & 897 & 1070 & 314 & 1041 & 535 & 450 & 337 & 878 & 1582 & 7201 \\
\hline $\mathrm{La}$ & 284 & 740 & 307 & 280 & 335 & 231 & 517 & 445 & 85.90 & 159 \\
\hline $\mathrm{Ce}$ & 434 & 1380 & 608 & 502 & 689 & 394 & 1170 & 789 & 95.80 & 204 \\
\hline $\operatorname{Pr}$ & 47 & 146 & 65.10 & 48.30 & 76.80 & 44.50 & 142 & 79.90 & 8.62 & 18.40 \\
\hline $\mathrm{Nd}$ & 152 & 505 & 241 & 166 & 299 & 166 & 583 & 284 & 29.50 & 57.60 \\
\hline $\mathrm{Sm}$ & 22.10 & 72.80 & 39.10 & 26.80 & 48.90 & 28.50 & 101 & 44.40 & 5.47 & 8.39 \\
\hline $\mathrm{Eu}$ & 5.93 & 20.50 & 11.10 & 7.95 & 14.50 & 8.60 & 28.20 & 13.10 & 1.92 & 3.21 \\
\hline $\mathrm{Gd}$ & 17.80 & 53.20 & 32.80 & 22.80 & 41.20 & 25.90 & 79.70 & 36.10 & 5.85 & 9.58 \\
\hline $\mathrm{Tb}$ & 2.35 & 6.90 & 4.35 & 3.33 & 5.14 & 3.36 & 9 & 4.60 & 0.94 & 1.72 \\
\hline Dy & 12.50 & 34.20 & 21.50 & 17.10 & 24.70 & 16.60 & 39.40 & 22.20 & 5.59 & 10.40 \\
\hline Ho & 2.41 & 6.02 & 3.87 & 3.20 & 4.14 & 2.90 & 6.07 & 3.97 & 1.30 & 2.14 \\
\hline Er & 6.40 & 14.80 & 10.70 & 9.22 & 10.90 & 7.85 & 14.90 & 10.70 & 4.47 & 6.68 \\
\hline $\mathrm{Tm}$ & 0.84 & 1.81 & 1.48 & 1.36 & 1.40 & 1.08 & 1.85 & 1.47 & 0.79 & 1.14 \\
\hline $\mathrm{Yb}$ & 5.09 & 10.80 & 8.41 & 9 & 7.80 & 6.09 & 9.92 & 8.76 & 5.54 & 7.83 \\
\hline $\mathrm{Lu}$ & 0.69 & 1.39 & 1.12 & 1.28 & 1.01 & 0.78 & 1.18 & 1.14 & 0.88 & 1.18 \\
\hline $\mathrm{Hf}$ & 0.06 & 0.08 & 1.50 & 0.20 & 1.30 & 1.60 & 0.60 & 0.50 & 0.20 & 0.30 \\
\hline $\mathrm{Zr}$ & 2.30 & 2.30 & 103 & 4 & 24 & 223 & 539 & 33 & 11 & 7 \\
\hline $\mathrm{Pb}$ & 1.46 & 10.10 & n.d. & n.d. & n.d. & n.d. & n.d. & n.d. & n.d. & n.d. \\
\hline Th & 0.44 & 8.45 & 7.05 & 1.95 & 32.10 & 6.65 & 38.90 & 10.60 & 11.90 & 25.20 \\
\hline $\mathrm{U}$ & 0.02 & 1.49 & 1.06 & 3.11 & 6.75 & 2.11 & 30.60 & 115 & 4.48 & 3.04 \\
\hline $\mathrm{Nb}$ & 2.95 & 13 & 10.80 & 4.60 & 14.90 & 51.10 & 69.10 & 255 & 7.50 & 15.20 \\
\hline$\sum \mathrm{REE}$ & 993.11 & 2993.42 & 1355.53 & 1098.34 & 1559.49 & 937.16 & 2703.22 & 1744.34 & 252.57 & 491.27 \\
\hline $\mathrm{Th} / \mathrm{U}$ & 22 & 5.67 & 6.65 & 0.62 & 4.75 & 3.15 & 1.27 & 0.09 & 2.65 & 8.28 \\
\hline$(\mathrm{La} / \mathrm{Yb})_{\mathrm{N}}$ & 40.04 & 49.17 & 26.20 & 22.33 & 30.82 & 27.22 & 37.40 & 36.45 & 11.13 & 14.57 \\
\hline $\mathrm{Eu} / \mathrm{Eu}^{*}$ & 0.88 & 0.96 & 0.92 & 0.96 & 0.96 & 0.95 & 0.93 & 0.97 & 1.03 & 1.09 \\
\hline $\mathrm{Sr} / \mathrm{Sr}^{*}$ & 21.99 & 9.64 & 17.58 & 17.58 & 14.01 & 23.53 & 12.29 & 18.52 & 28.01 & 24.25 \\
\hline
\end{tabular}

Note. In the sample references, Fuerteventura analyses are from Hoernle et al., 2002 [20], and Cape Verde analyses are from Doucelance et al., $2010[12] . \mathrm{Eu}^{*}=\mathrm{Eu}_{\mathrm{N}} /\left(\mathrm{Sm}_{\mathrm{N}} \times \mathrm{Gd}_{\mathrm{N}}\right)^{1 / 2} ; \mathrm{Sr}^{*}=\left(\mathrm{Ce}_{\mathrm{N}}+\mathrm{Nd}_{\mathrm{N}}\right)^{1 / 2}$. n.d. $=$ not determined. 
Table A2. Literature trace element compositions of calcite and apatite in Cape Verde carbonatites.

\begin{tabular}{|c|c|c|c|c|c|c|}
\hline \multirow{3}{*}{$\begin{array}{c}\text { Occurrence } \\
\text { Mineral } \\
\text { Sample }\end{array}$} & \multicolumn{2}{|c|}{ Brava } & \multicolumn{2}{|c|}{ Fogo } & \multicolumn{2}{|c|}{ S. Vicente } \\
\hline & \multicolumn{6}{|c|}{ Calcite } \\
\hline & Br-15 & Br-23 & F-211C & F-230B & SV-186 & SV-188 \\
\hline Mn (ppm) & n.d. & n.d. & n.d. & n.d. & n.d. & n.d. \\
\hline $\mathrm{Sr}$ & $>1000$ & $>1000$ & $>1000$ & $>1000$ & $>1000$ & $>1000$ \\
\hline $\mathrm{Y}$ & 92.50 & 83.70 & 99 & 81.50 & 24.20 & 101 \\
\hline $\mathrm{Rb}$ & 1 & 0.80 & 0.80 & 1.10 & 0.90 & 1 \\
\hline $\mathrm{Ba}$ & 467 & 613 & 596 & 554 & 603 & 2310 \\
\hline $\mathrm{La}$ & 260 & 201 & 285 & 206 & 56.40 & 119 \\
\hline $\mathrm{Ce}$ & 456 & 349 & 530 & 330 & 61.40 & 158 \\
\hline $\operatorname{Pr}$ & n.d. & n.d. & n.d. & n.d. & n.d. & n.d. \\
\hline $\mathrm{Nd}$ & 172 & 129 & 214 & 128 & 18.70 & 53.40 \\
\hline Sm & 25.20 & 19.20 & 32.80 & 20.10 & 3.10 & 8.40 \\
\hline $\mathrm{Eu}$ & 7.30 & 6.10 & 9.60 & 6.30 & 1.10 & 3.70 \\
\hline $\mathrm{Gd}$ & n.d. & n.d. & n.d. & n.d. & n.d. & n.d. \\
\hline $\mathrm{Tb}$ & 3.10 & 2.60 & 3.70 & 2.60 & 0.50 & 2.50 \\
\hline Dy & n.d. & n.d. & n.d. & n.d. & n.d. & n.d. \\
\hline Ho & n.d. & n.d. & n.d. & n.d. & n.d. & n.d. \\
\hline $\mathrm{Er}$ & n.d. & n.d. & n.d. & n.d. & n.d. & n.d. \\
\hline $\mathrm{Tm}$ & n.d. & n.d. & n.d. & n.d. & n.d. & n.d. \\
\hline $\mathrm{Yb}$ & 8.20 & 8.70 & 7.40 & 5.90 & 2.60 & 9.50 \\
\hline $\mathrm{Lu}$ & 1.10 & 1.20 & 1 & 0.80 & 0.40 & 1.30 \\
\hline Hf & $<0.1$ & $<0.1$ & $<0.1$ & $<0.1$ & $<0.1$ & $<0.1$ \\
\hline $\mathrm{Zr}$ & 0.80 & 0.60 & 0.50 & 1.10 & 12.70 & 8 \\
\hline $\mathrm{Pb}$ & n.d. & n.d. & n.d. & n.d. & n.d. & n.d. \\
\hline Th & 1.70 & 0.90 & 2.50 & 0.40 & 3.80 & 20.40 \\
\hline $\mathrm{U}$ & 0.10 & 0.20 & 0.60 & 0.30 & 1.40 & 2.70 \\
\hline $\mathrm{Nb}$ & 0.90 & 0.10 & 3 & 5.50 & 0.60 & 1.40 \\
\hline$\sum \mathrm{REE}$ & n.d. & n.d. & n.d. & n.d. & n.d. & n.d. \\
\hline$\overline{\mathrm{T}} \mathrm{h} / \mathrm{U}$ & 17 & 4.50 & 4.17 & 1.33 & 2.71 & 7.56 \\
\hline$(\mathrm{La} / \mathrm{Yb})_{\mathrm{N}}$ & 22.75 & 16.58 & 27.64 & 25.06 & 15.57 & 8.99 \\
\hline $\mathrm{Eu} / \mathrm{Eu}^{*}$ & n.d. & n.d. & n.d. & n.d. & n.d. & n.d. \\
\hline $\mathrm{Sr} / \mathrm{Sr}^{*}$ & n.d. & n.d. & n.d. & n.d. & n.d. & n.d. \\
\hline$\delta \mathrm{Ce}$ & n.d. & n.d. & n.d. & n.d. & n.d. & n.d. \\
\hline$\delta \mathrm{Eu}$ & n.d. & n.d. & n.d. & n.d. & n.d. & n.d. \\
\hline$\delta \mathrm{Y}$ & n.d. & n.d. & n.d. & n.d. & n.d. & n.d. \\
\hline Occurrence & \multicolumn{2}{|c|}{ Brava } & \multicolumn{2}{|c|}{ Fogo } & \multicolumn{2}{|c|}{ Santiago } \\
\hline Mineral & \multicolumn{6}{|c|}{ Apatite } \\
\hline Sample & \multicolumn{2}{|c|}{ Br-15 } & F-211C & F-230B & S-309 & S-311 \\
\hline Mn (ppm) & \multicolumn{2}{|c|}{ n.d. } & n.d. & n.d. & n.d. & n.d. \\
\hline $\mathrm{Sr}$ & \multicolumn{2}{|c|}{$>1000$} & $>1000$ & $>1000$ & $>1000$ & $>1000$ \\
\hline $\mathrm{Y}$ & \multicolumn{2}{|c|}{228} & 402 & 317 & 285 & 223 \\
\hline $\mathrm{Rb}$ & \multicolumn{2}{|c|}{1.70} & 0.50 & 8.50 & 0.50 & 1.20 \\
\hline $\mathrm{Ba}$ & \multicolumn{2}{|c|}{671} & 397 & 137 & 376 & 881 \\
\hline $\mathrm{La}$ & \multicolumn{2}{|c|}{834} & 1560 & 983 & 1120 & 1010 \\
\hline $\mathrm{Ce}$ & \multicolumn{2}{|c|}{1930} & 3500 & 2000 & 2850 & 2310 \\
\hline $\operatorname{Pr}$ & & & n.d. & n.d. & n.d. & n.d. \\
\hline $\mathrm{Nd}$ & & & 1700 & 967 & 1480 & 919 \\
\hline Sm & & & $>100$ & $>100$ & $>100$ & $>100$ \\
\hline $\mathrm{Eu}$ & & & 79.60 & 52.80 & 69.50 & 43.90 \\
\hline $\mathrm{Gd}$ & & & n.d. & n.d. & n.d. & n.d. \\
\hline $\mathrm{Tb}$ & & & 25.40 & 16.80 & 20 & 13.40 \\
\hline Dy & & & n.d. & n.d. & n.d. & n.d. \\
\hline Ho & & & n.d. & n.d. & n.d. & n.d. \\
\hline $\mathrm{Er}$ & & & n.d. & n.d. & n.d. & n.d. \\
\hline $\mathrm{Tm}$ & & & n.d. & n.d. & n.d. & n.d. \\
\hline $\mathrm{Yb}$ & & & 20.90 & 15.50 & 14 & 11.30 \\
\hline $\mathrm{Lu}$ & & & 2.20 & 1.60 & 1.70 & 1.20 \\
\hline
\end{tabular}


Table A2. Cont.

\begin{tabular}{cccccc}
\hline Occurrence & Brava & \multicolumn{2}{c}{ Fogo } & \multicolumn{2}{c}{ Santiago } \\
\hline Mineral & \multicolumn{2}{c}{ Apatite } \\
\hline Sample & Br-15 & F-211C & F-230B & S-309 & S-311 \\
\hline $\mathrm{Hf}$ & 0.30 & 0.30 & 0.20 & 0.20 & 0.10 \\
$\mathrm{Zr}$ & 7.50 & 18.10 & 13.40 & 8.70 & 13.20 \\
$\mathrm{~Pb}$ & n.d. & n.d. & n.d. & n.d. & n.d. \\
$\mathrm{Th}$ & 39.50 & 133 & 44.20 & 55.80 & 30.20 \\
$\mathrm{U}$ & 3.40 & 13.90 & 11 & 7.60 & 1 \\
$\mathrm{Nb}$ & 1.20 & 20 & 9.90 & 3.30 & 4.60 \\
$\sum \mathrm{REE}$ & n.d. & n.d. & n.d. & n.d. & n.d. \\
$\mathrm{Th} / \mathrm{U}$ & 11.62 & 9.57 & 4.02 & 7.34 & 30.20 \\
$(\mathrm{La} / \mathrm{Yb})_{\mathrm{N}}$ & 44.66 & 53.56 & 45.51 & 57.41 & 64.14 \\
$\mathrm{Eu} / \mathrm{Eu}$ & n.d. & n.d. & n.d. & n.d. & n.d. \\
$\mathrm{Sr} / \mathrm{Sr} *$ & n.d. & n.d. & n.d. & n.d. & n.d. \\
$\delta \mathrm{Ce}$ & n.d. & n.d. & n.d. & n.d. & n.d. \\
$\delta \mathrm{Eu}$ & n.d. & n.d. & n.d. & n.d. & n.d. \\
$\delta \mathrm{Y}$ & n.d. & n.d. & n.d. & n.d. & n.d.
\end{tabular}

Note. In the sample references, Cape Verde analyses are from Doucelance et al., 2010 [12]. n.d. = not determined.

Table A3. $\delta \mathrm{Eu}, \delta \mathrm{Y}$, and $\delta \mathrm{Ce}$ of apatites from Fuerteventura carbonatites plotted in Figure 5.

\begin{tabular}{llcl}
\hline Occurrence & \multicolumn{3}{c}{ Fuerteventura } \\
\hline Apatite & $\delta$ Ce & $\delta$ Eu & $\delta$ Y \\
2_1CX02 & & & \\
2_1CX03 & 1.09 & 0.84 & 0.79 \\
2_1CX04 & 1.07 & 0.84 & 0.80 \\
2_1CX05 & 1.09 & 0.83 & 0.85 \\
2_1CX06 & 1.09 & 0.84 & 0.83 \\
2_1CX07 & 1.09 & 0.89 & 0.78 \\
2_1CX08 & 1.04 & 0.82 & 0.80 \\
2_1CX09 & 1.06 & 0.87 & 0.82 \\
2_1CY02 & 1.07 & 0.87 & 0.84 \\
2_1CY03 & 1.05 & 0.87 & 0.82 \\
2_1CY04 & 1.04 & 0.86 & 0.81 \\
2_1CY05 & 1.07 & 0.86 & 0.79 \\
2_1CY06 & 1.04 & 0.87 & 0.79 \\
2_1CY07 & 1.05 & 0.87 & 0.77 \\
2_1CZ01 & 1.03 & 0.87 & 0.87 \\
2_1CZ02 & 0.97 & 0.90 & 0.84 \\
2_1CZ03 & 0.98 & 0.91 & 0.86 \\
2_1CZ04 & 0.99 & 0.87 & 0.81 \\
2_1CZ05 & 1.04 & 0.86 & 0.82 \\
2_1CZ06 & 1.06 & 0.89 & 0.81 \\
2_1CZ07 & 1.06 & 0.88 & 0.88 \\
\hline
\end{tabular}

Note. See Section 5.1 .1 in the text for $\delta \mathrm{Ce}, \delta \mathrm{Eu}$, and $\delta \mathrm{Y}$ calculations. 
Table A4. Th and $\mathrm{U}$ concentrations and related $4 \mathrm{He}^{*}$ production in mineral separates from Cape Verde carbonatites.

\begin{tabular}{ccccc}
\hline Mineral Type & Th $(\mathbf{p p m})$ & $\mathbf{U}(\mathbf{p p m})$ & Age $(\mathbf{M a})$ & ${ }^{4} \mathbf{H e}^{*}(\mu \mathrm{ccSTP} / \mathbf{g})$ \\
\hline $\begin{array}{c}\text { Carbonatite } \\
\text { Apatite }\end{array}$ & & & & \\
Br-15 & 39.5 & 3.4 & 2 & 3.0 \\
F-230B & 44.2 & 11.0 & 4 & 10.3 \\
S-309 & 55.8 & 7.6 & 9 & 22.4 \\
Calcite & & & & \\
Br-23 & 0.9 & 0.2 & 2 & 0.1 \\
F-230B & 0.4 & 0.3 & 4 & 0.2 \\
SV-186 & 3.8 & 1.4 & 5.7 & 5.6 \\
SV-188 & 20.4 & 2.7 & 5.7 & 5.1 \\
\hline
\end{tabular}

Note. Analysis and ages from Mata et al., 2010 [23]. The equation ${ }^{4} \mathrm{He}^{*} \approx 2.8 \times 10^{-8}(4.35+\mathrm{Th} / \mathrm{U}) \cdot(\mathrm{U}) \cdot(\mathrm{t})$ was used to calculate the ${ }^{4} \mathrm{He}^{*}$ radiogenic (from Mata et al., 2010 [23]). [Th] and [U] in ppm, $\mathrm{t}$ in Ma.

Table A5. He concentrations (ccSTP/g) and He, Ne, and Ar isotopic ratios in mineral separates from Cape Verde carbonatites.

\begin{tabular}{|c|c|c|c|c|c|c|c|c|c|c|c|}
\hline Mineral Type & $\begin{array}{c}{ }^{4} \mathrm{He} \\
\left(10^{-7}\right)\end{array}$ & $\begin{array}{c}{ }^{3} \mathrm{He} \\
\left(10^{-12}\right)\end{array}$ & $\mathbf{R} / \mathbf{R a}$ & $1 \sigma$ & ${ }^{4} \mathrm{He} /{ }^{20} \mathrm{Ne}$ & ${ }^{20} \mathrm{Ne} /{ }^{22} \mathrm{Ne}$ & $1 \sigma$ & ${ }^{21} \mathrm{Ne} /{ }^{22} \mathrm{Ne}$ & $1 \sigma$ & ${ }^{40} \mathrm{Ar} /{ }^{36} \mathrm{Ar}$ & $1 \sigma$ \\
\hline \multicolumn{12}{|l|}{$\begin{array}{c}\text { Carbonatite } \\
\text { Apatite }\end{array}$} \\
\hline Br-15 step 1 & 0.69 & 0.93 & 9.76 & 0.51 & 1000.4 & 10.34 & 0.04 & 0.0314 & 0.0008 & 624 & 2 \\
\hline F-230B step 1 & 1.07 & 0.10 & 0.67 & 0.14 & 508.4 & 9.88 & 0.03 & 0.0293 & 0.0005 & 531 & 2 \\
\hline \multicolumn{11}{|l|}{ Calcite } & 9 \\
\hline $\mathrm{Br}-23$ & 1.6 & 2.00 & 9.02 & 0.71 & 172 & 9.89 & 0.02 & 0.0301 & 0.0005 & 363 & 19 \\
\hline F-230B & 1.1 & 1.02 & 6.71 & 0.43 & 738 & 9.86 & 0.05 & 0.0318 & 0.0011 & 414 & 21 \\
\hline SV-186 step 1 & 5.1 & 10.91 & 15.5 & 0.22 & 850 & 9.83 & 0.02 & 0.0289 & 0.0005 & 354 & 18 \\
\hline SV-188 & 8.3 & 14.45 & 12.6 & 0.20 & 5460 & 9.83 & 0.02 & 0.0294 & 0.0004 & 363 & 19 \\
\hline Air & & & 1.00 & & & 9.80 & & 0.0290 & & $\begin{array}{c}298.6 \\
+/-0.3\end{array}$ & \\
\hline
\end{tabular}

Note. Analysis from Mata et al., 2010 [23]. The atmospheric value for ${ }^{20} \mathrm{Ne} /{ }^{22} \mathrm{Ne}$ and ${ }^{21} \mathrm{Ne} /{ }^{22} \mathrm{Ne}$ was taken from Ozima and Podosek, 2002 [73], while that for ${ }^{40} \mathrm{Ar} /{ }^{36} \mathrm{Ar}$ was taken from Lee et al. 2006 [74].

\section{References}

1. Le Maitre, R.; Streckeisen, A.; Zanettin, B.; Le Bas, M.J.; Bonin, B.; Bateman, P. Igneous Rocks: A Classification and Glossary of Terms (Recommendations of the IUGS Subcommission on the Systematics of Igneous Rocks), 2nd ed.; Cambridge University Press: Cambridge, UK, 2002.

2. Wolley, A.R.; Kjarsgaard, B.A. Carbonatite occurrences of the world: Map and database. Geol. Surv. Canada 2008, 5796, 1-28. [CrossRef]

3. Jones, A.P.; Genge, M.; Carmody, L. Carbonate melts and carbonatites. Rev. Mineral. Geochem. 2013, 75, 289-322. [CrossRef]

4. Wyllie, P.J.; Huang, W.L. Peridotite, kimberlite, and carbonatite explained in the system CaO-MgO-SiO $-\mathrm{CO}_{2}$. Geology 1975,3 , 621-624. [CrossRef]

5. Wallace, M.E.; Green, D.H. An experimental determination of primary carbonatite magma composition. Nature 1988, 335, 343-346. [CrossRef]

6. Wyllie, P.J.; Lee, W.J. Model system controls on conditions for formation of magnesiocarbonatite and calciocarbonatite magmas from the mantle. J. Petrol. 1998, 39, 1885-1893. [CrossRef]

7. Brooker, R.A. The effect of $\mathrm{CO}_{2}$ saturation on immiscibility between silicate and carbonate liquids: An experimental study. J. Petrol. 1998, 39, 1905-1915. [CrossRef]

8. Brooker, R.A.; Kjarsgaard, B.A. Silicate-carbonate liquid immiscibility and phase relations in the system $\mathrm{SiO}_{2}-\mathrm{Na}_{2} \mathrm{O}-\mathrm{Al}_{2} \mathrm{O}_{3}-\mathrm{Cao}-$ $\mathrm{CO}_{2}$ at 0.1-2.5 GPa with applications to carbonatite genesis. J. Petrol. 2011, 52, 1281-1305. [CrossRef]

9. Lee, W.J.; Wyllie, P.J. Experimental data bearing on liquid immiscibility, crystal fractionation, and the origin of calciocarbonatites and natrocarbonatites. Int. Geol. Rev. 1994, 36, 797-819. [CrossRef]

10. Veksler, I.V.; Nielsen, T.F.D.; Sokolov, S.V. Mineralogy of crystallized melt inclusions from Gardiner and Kovdor ultramafic alkaline complexes: Implications for carbonatite genesis. J. Petrol. 1998, 39, 2015-2031. [CrossRef] 
11. Demény, A.; Ahijado, A.; Casillas, R.; Vennemann, T.W. Crustal contamination and fluid/rock interaction in the carbonatites of Fuerteventura (Canary Islands, Spain): A C, O, H isotope study. Lithos 1998, 44, 101-115. [CrossRef]

12. Doucelance, R.; Hammouda, T.; Moreira, M.; Martins, J.C. Geochemical constraints on depth of origin of oceanic carbonatites: The Cape Verde case. Geochim. Cosmochim. Acta 2010, 74, 7261-7282. [CrossRef]

13. Park, J.; Rye, D.M. Broader Impacts of the Metasomatic Underplating Hypothesis. Geochem. Geophys. Geosyst. 2019, 20, 4180-4829. [CrossRef]

14. Doucelance, R.; Bellot, N.; Boyet, M.; Hammouda, T.; Bosq, C. What coupled cerium and neodymium isotopes tell us about the deep source of oceanic carbonatites. Earth Planet. Sci. Lett. 2014, 407, 175-186. [CrossRef]

15. Hammouda, T.; Chantel, J.; Manthilake, G.; Guignard, J.; Crichton, W. Hot mantle geotherms stabilize calcic carbonatite magmas up to the surface. Geology 2014, 42, 911-914. [CrossRef]

16. Dalton, J.A.; Wood, B.J. The compositions of primary carbonate melts and their evolution through wallrock reaction in the mantle. Earth Planet. Sci. Lett. 1993, 119, 511-525. [CrossRef]

17. Hammouda, T. High-pressure melting of carbonated eclogite and experimental constraints on carbon recycling and storage in the mantle. Earth Planet. Sci. Lett. 2003, 214, 357-368. [CrossRef]

18. Yaxley, G.M.; Brey, G.P. Phase relations of carbonate-bearing eclogite assemblages from 2.5 to 5.5 GPa: Implications for petrogenesis of carbonatites. Contrib. Mineral. Petrol. 2004, 146, 606-619. [CrossRef]

19. Dasgupta, R.; Hirschmann, M.M.; Withers, A.C. Deep global cycling of carbon constrained by the solidus of anhydrous, carbonated eclogite under upper mantle conditions. Earth Planet. Sci. Lett. 2004, 227, 73-85. [CrossRef]

20. Hoernle, K.; Tilton, G.; Le Bas, M.J.; Duggen, S.; Garbe-Schönberg, D. Geochemistry of oceanic carbonatites compared with continental carbonatites: Mantle recycling of oceanic crustal carbonate. Contrib. Mineral. Petrol. 2002, 142, 520-542. [CrossRef]

21. De Ignacio, C.; Muñoz, M.; Sagredo, J.; Fernández-Santín, S.; Johansson, Å. Isotope geochemistry and FOZO mantle component of the alkaline-carbonatitic association of Fuerteventura, Canary Islands, Spain. Chem. Geol. 2006, 232, 99-113. [CrossRef]

22. De Ignacio, C.; Muñoz, M.; Sagredo, J. Carbonatites and associated nephelinites from São Vicente, Cape Verde Islands. Mineral. Mag. 2012, 76, 311-355. [CrossRef]

23. Mata, J.; Moreira, M.; Doucelance, R.; Ader, M.; Silva, L.C. Noble gas and carbon isotopic signatures of Cape Verde oceanic carbonatites: Implications for carbon provenance. Earth Planet. Sci. Lett. 2010, 291, 70-83. [CrossRef]

24. Hoernle, K.A.; Tilton, G.R. Sr-Nd-Pb isotope data for Fuerteventura (Canary Islands). Schweizerische Mineral. Petrogr. Mitteilungen 1991, 71, 3-18.

25. Mourão, C.; Mata, J.; Doucelance, R.; Madeira, J.; Millet, M.A.; Moreira, M. Geochemical temporal evolution of Brava Island magmatism: Constraints on the variability of Cape Verde mantle sources and on carbonatite-silicate magma link. Chem. Geol. 2012, 334, 44-61. [CrossRef]

26. Zindler, A.; Hart, S. Chemical geodynamics. Annu. Rev. Earth Planet. Sci. 1986, 14, 493-571. [CrossRef]

27. Allègre, C.J. Isotope geodynamics. Earth Planet. Sci. Lett. 1987, 86, 175-203. [CrossRef]

28. Porcelli, D.; Wasserburg, G.J. Mass transfer of helium, neon, argon, and xenon through a steady-state upper mantle. Geochim. Cosmochim. Acta 1995, 59, 4921-4937. [CrossRef]

29. Montelli, R.; Nolet, G.; Dahlen, F.A.; Masters, G. A catalogue of deep mantle plumes: New results from finite frequency tomography. Geochem. Geophys. Geosyst. 2006, 7, 1-69. [CrossRef]

30. Zhao, D. Seismic images under 60 hotspots: Search for mantle plumes. Gondwana Res. 2007, 12, 335-355. [CrossRef]

31. Roeser, H.A. Magnetic anomalies in the magnetic quiet zone off Morocco. In Proceedings of the Geology of the Northwest African Continental Margin; von Rad, U., Hinz, K., Sarnthein, M., Seibold, E., Eds.; Springer: Berlin, Heidelberg, 1982.

32. Klitgord, K.D.; Schouten, H. Plate kinematics of the central Atlantic. In The Western North Atlantic Region; Vogt, P.R., Tucholke, B.E., Eds.; Geological Society of America: Boulder, CO, USA, 1986; pp. 351-378.

33. Roest, W.R.; Dañobeitia, J.J.; Verhoef, J.; Collette, B.J. Magnetic anomalies in the canary basin and the Mesozoic evolution of the central North Atlantic. Mar. Geophys. Res. 1992, 14, 1-24. [CrossRef]

34. Hoernle, K. Geochemistry of Jurassic oceanic crust beneath Gran Canaria (Canary Islands): Implications for crustal recycling and assimilation. J. Petrol. 1998, 39, 859-880. [CrossRef]

35. Martinez-Arevalo, C.; Mancilla, F.d.L.; Helffrich, G.; Garcia, A. Seismic evidence of a regional sublithospheric low velocity layer beneath the Canary Islands. Tectonophysics 2013, 608, 586-599. [CrossRef]

36. Fúster, J.M.; Cendrero, A.; Gastesi, P.; Ibarrola, E.; Lopez Ruiz, J. Geología y Volcanología de las Islas Canarias-Fuerteventura; Consejo Superior de Investigaciones Científicas, Instituto “Lucas Mallada": Madrid, Spain, 1968.

37. Stillman, C.J.; Bennell-baker, M.J.; Smewing, J.D.; Fúster, J.M.; Muñoz, M.; Sagredo, J. Basal complex of Fuerteventura (Canary Islands) is an oceanic intrusive complex with rift-system affinities. Nature 1975, 257, 469-471. [CrossRef]

38. Le Bas, M.J.; Rex, D.C.; Stillman, C.J. The early magmatic chronology of Fuerteventura, Canary Islands. Geol. Mag. 1986, 123, 287-298. [CrossRef]

39. Coello, J.; Cantagrel, J.M.; Hernán, F.; Fúster, J.M.; Ibarrola, E.; Ancochea, E.; Casquet, C.; Jamond, C.; Díaz de Téran, J.R.; Cendrero, A. Evolution of the eastern volcanic ridge of the Canary Islands based on new KAr data. J. Volcanol. Geotherm. Res. 1992, 53, 251-274. [CrossRef]

40. Ancochea, E.; Brändle, J.L.; Cubas, C.R.; Hernán, F.; Huertas, M.J. Volcanic complexes in the eastern ridge of the Canary Islands: The Miocene activity of the island of Fuerteventura. J. Volcanol. Geotherm. Res. 1996, 70, 183-204. [CrossRef] 
41. Steiner, C.; Hobson, A.; Favre, P.; Stampfli, G.M.; Hernandez, J. Mesozoic sequence of Fuerteventura (Canary Islands): Witness of early Jurassic sea-floor spreading in the central Atlantic. Bull. Geol. Soc. Am. 1998, 110, 1304-1317. [CrossRef]

42. Balogh, K.; Ahijado, A.; Casillas, R.; Fernández, C. Contributions to the chronology of the Basal Complex of Fuerteventura, Canary Islands. J. Volcanol. Geotherm. Res. 1999, 90, 81-102. [CrossRef]

43. Muñoz, M.; Sagredo, J.; de Ignacio, C.; Fernández-Suárez, J.; Jeffries, T.E. New data (U-Pb, K-Ar) on the geochronology of the alkaline-carbonatitic association of Fuerteventura, Canary Islands, Spain. Lithos 2005, 85, 140-153. [CrossRef]

44. Fernández, C.; Casillas, R.; García-Navarro, E.; Gutiérrez, M.; Camacho, M.A.; Ahijado, A. Miocene rifting of Fuerteventura (Canary Islands). Tectonics 2006, 5, 127-140. [CrossRef]

45. Gutiérrez, M.; Casillas, R.; Fernández, C.; Balogh, K.; Ahijado, A.; Castillo, C.; Colmenero, J.R.; García-Navarro, E. The submarine volcanic succession of the basal complex of Fuerteventura, Canary Islands: A model of submarine growth and emergence of tectonic volcanic islands. Bull. Geol. Soc. Am. 2006, 118, 785-804. [CrossRef]

46. Gutiérrez, M. Estudio Petrológico, Geoquímico y Estructural de la Serie Volcánica Submarina del Complejo Basal de Fuerteventura (Islas Canarias): Caracterización del Crecimiento Submarino y de la Emersión de la Isla; Universidad de La Laguna: La Laguna, Spain, 2000

47. Hobson, A.; Bussy, F.; Hernandez, J. Shallow-level migmatization of gabbros in a metamorphic contact aureole, Fuerteventura basal complex, Canary Islands. J. Petrol. 1998, 39, 125-137. [CrossRef]

48. Casillas, R.; Demény, A.; Nagy, G.; Ahijado, A.; Fernández, C. Metacarbonatites in the Basal Complex of Fuerteventura (Canary Islands). The role of fluid/rock interactions during contact metamorphism and anatexis. Lithos 2011, 125, 503-520. [CrossRef]

49. Carnevale, G.; Arroyo Rey, X.; Correale, A.; Rotolo, S.G. Procesos hidrotermales con enriquecimiento en REE en las carbonatitas de Fuerteventura: Evidencias en minerales accesorios. Geogaceta 2020, 69, 23-26.

50. Zazo, C.; Goy, J.L.; Hillaire-Marcel, C.; Gillot, P.Y.; Soler, V.; González, J.Á.; Dabrio, C.J.; Ghaleb, B. Raised marine sequences of Lanzarote and Fuerteventura revisited-A reappraisal of relative sea-level changes and vertical movements in the eastern Canary Islands during the Quaternary. Quat. Sci. Rev. 2002, 21, 2019-2046. [CrossRef]

51. Williams, C.A.; Hill, A.; Young, R.; White, R.S. Fracture zones across the Cape Verde Rise, NE Atlantic. J. Geol. Soc. London 1990, 147, 851-857. [CrossRef]

52. Lodge, A.; Helffrich, G. Depleted swell root beneath the Cape Verde Islands. Geology 2006, 34, 449-452. [CrossRef]

53. Pim, J.; Peirce, C.; Watts, A.B.; Grevemeyer, I.; Krabbenhoeft, A. Crustal structure and origin of the Cape Verde Rise. Earth Planet. Sci. Lett. 2008, 272, 422-428. [CrossRef]

54. Holm, P.M.; Grandvuinet, T.; Friis, J.; Wilson, J.R.; Barker, A.K.; Plesner, S. An 40Ar-39Ar study of the Cape Verde hot spot: Temporal evolution in a semistationary plate environment. J. Geophys. Res. Solid Earth 2008, 113, 1-22. [CrossRef]

55. Torres, P.; Silva, L.C.; Munhá, J.; Caldeira, R.; Mata, J.; Tassinari, C. Petrology and geochemistry of lavas from Sal Island: Implications for the variability of the Cape Verde magmatism. Comun. Geol. 2010, 97, 35-62.

56. Mitchell, J.G.; Le Bas, M.J.; Zielonka, J.; Furnes, H. On dating the magmatism of Maio, Cape Verde Islands. Earth Planet. Sci. Lett. 1983, 64, 61-76. [CrossRef]

57. Plesner, S.; Holm, P.M.; Wilson, J.R. 40-39Ar geochronology of Santo Antão, Cape Verde Islands. J. Volcanol. Geotherm. Res. 2003, 120, 103-121. [CrossRef]

58. Huertas, M.J.; Hernán, F.; Ancochea, E.; Brändle, J.L. El Edificio Antiguo de la isla de San Vicente (Cabo Verde): Características del sector occidental. Geogaceta 2006, 40, 95-98.

59. Ancochea, E.; Huertas, M.J.; Hernán, F.; Brändle, J.L. Volcanic evolution of São Vicente, Cape Verde Islands: The Praia Grande landslide. J. Volcanol. Geotherm. Res. 2010, 198, 143-157. [CrossRef]

60. Mata, J.; Martins, S.; Mattielli, N.; Madeira, J.; Faria, B.; Ramalho, R.S.; Silva, P.; Moreira, M.; Caldeira, R.; Moreira, M.; et al. The 2014-15 eruption and the short-term geochemical evolution of the Fogo volcano (Cape Verde): Evidence for small-scale mantle heterogeneity. Lithos 2017, 288-289, 91-107. [CrossRef]

61. Holm, P.M.; Wilson, J.R.; Christensen, B.P.; Hansen, L.; Hansen, S.L.; Hein, K.M.; Mortensen, A.K.; Pedersen, R.; Plesner, S.; Runge, M.K. Sampling the Cape Verde Mantle Plume: Evolution of melt compositions on Santo Antão, Cape Verde Islands. J. Petrol. 2006, 47, 145-189. [CrossRef]

62. Duprat, H.I.; Friis, J.; Holm, P.M.; Grandvuinet, T.; Sørensen, R.V. The volcanic and geochemical development of São Nicolau, Cape Verde Islands: Constraints from field and 40Ar/39Ar evidence. J. Volcanol. Geotherm. Res. 2007, 162, 1-19. [CrossRef]

63. Mourão, C.; Mata, J.; Doucelance, R.; Madeira, J.; da Silveira, A.B.; Silva, L.C.; Moreira, M. Quaternary extrusive calciocarbonatite volcanism on Brava Island (Cape Verde): A nephelinite-carbonatite immiscibility product. J. African Earth Sci. 2010, 56, 59-74. [CrossRef]

64. Kogarko, L.N. Geochemical characteristics of oceanic carbonatites from the Cape Verde Islands. South Afr. J. Geol. 1993, 96, 119-125.

65. Sagan, M.; Heaman, L.M.; Pearson, D.G.; Luo, Y.; Stern, R.A. Removal of continental lithosphere beneath the Canary archipelago revealed from a $\mathrm{U}-\mathrm{Pb}$ Age and $\mathrm{Hf} / \mathrm{O}$ isotope study of modern sand detrital zircons. Lithos 2020, 362-363, 1-18. [CrossRef]

66. Amsellem, E.; Moynier, F.; Moynier, F.; Bertrand, H.; Bouyon, A.; Mata, J.; Tappe, S.; Day, J.M.D. Calcium isotopic evidence for the mantle sources of carbonatites. Sci. Adv. 2020, 6, 1-6. [CrossRef]

67. Hart, S.R. A large-scale isotope anomaly in the Southern Hemisphere mantle. Nature 1984, 309, 753-757. [CrossRef]

68. Thirlwall, M.F. Pb isotopic and elemental evidence for OIB derivation from young HIMU mantle. Chem. Geol. 1997, 139, 51-74. [CrossRef] 
69. Bouabdellah, M.; Hoernle, K.; Kchit, A.; Duggen, S.; Hauff, F.; Klügel, A.; Lowry, D.; Beaudoin, G. Petrogenesis of the Eocene Tamazert continental carbonatites (Central High Atlas, Morocco): Implications for a common source for the Tamazert and Canary and Cape Verde Island carbonatites. J. Petrol. 2010, 51, 1655-1686. [CrossRef]

70. Duggen, S.; Hoernle, K.A.; Hauff, F.; Klügel, A.; Bouabdellah, M.; Thirlwall, M.F. Flow of Canary mantle plume material through a subcontinental lithospheric corridor beneath Africa to the Mediterranean. Geology 2009, 37, 283-286. [CrossRef]

71. Rizzo, A.L.; Pelorosso, B.; Coltorti, M.; Ntaflos, T.; Bonadiman, C.; Matusiak-Małek, M.; Italiano, F.; Bergonzoni, G. Geochemistry of noble gases and $\mathrm{CO}_{2}$ in fluid inclusions from lithospheric mantle beneath wilcza góra (Lower silesia, southwest Poland). Front. Earth Sci. 2018, 6, 215. [CrossRef]

72. Rizzo, A.L.; Uysal, I.T.; Mutlu, H.; Ünal-İmer, E.; Dirik, K.; Yüce, G.; Caracausi, A.; Italiano, F.; Misseri, M.; Temel, A.; et al. Geochemistry of Fluid Inclusions in Travertines From Western and Northern Turkey: Inferences on the Role of Active Faults in Fluids Circulation. Geochem. Geophys. Geosyst. 2019, 20, 5473-5498. [CrossRef]

73. Ozima, M.; Podosek, F.A. Noble Gas Geochemistry, 2nd ed.; Cambridge University Press: Cambridge, UK, 2002.

74. Lee, J.Y.; Marti, K.; Severinghaus, J.P.; Kawamura, K.; Yoo, H.S.; Lee, J.B.; Kim, J.S. A redetermination of the isotopic abundances of atmospheric Ar. Geochim. Cosmochim. Acta 2006, 70, 4507-4512. [CrossRef]

75. Hammouda, T.; Keshav, S. Melting in the mantle in the presence of carbon: Review of experiments and discussion on the origin of carbonatites. Chem. Geol. 2015, 418, 171-188. [CrossRef]

76. Dasgupta, R.; Hirschmann, M.M.; McDonough, W.F.; Spiegelman, M.; Withers, A.C. Trace element partitioning between garnet lherzolite and carbonatite at 6.6 and $8.6 \mathrm{GPa}$ with applications to the geochemistry of the mantle and of mantle-derived melts. Chem. Geol. 2009, 262, 57-77. [CrossRef]

77. Ahijado, A.; Casillas, R.; Nagy, G.; Fernández, C. Sr-rich minerals in a carbonatite skarn, Fuerteventura, Canary Islands (Spain). Mineral. Petrol 2005, 84, 107-127. [CrossRef]

78. McDonough, W.F.; Sun, S.S. The composition of the Earth. Chem. Geol. 1995, 120, 223-253. [CrossRef]

79. Sun, S.S.; McDonough, W.F. Chemical and isotopic systematics of oceanic basalts: Implications for mantle composition and processes. In Magmatism in the Ocean Basins; Saunders, A.D., Norry, M.J., Eds.; Geological Society: London, UK, 1989 ; pp. 313-345.

80. Schmidt, M.W.; Weidendorfer, D. Carbonatites in oceanic hotspots. Geology 2018, 46, 435-438. [CrossRef]

81. Chakhmouradian, A.R.; Zaitsev, A.N. Rare earth mineralization in igneous rocks: Sources and processes. Elements 2012, 8 , 347-353. [CrossRef]

82. Chakhmouradian, A.R.; Reguir, E.P.; Zaitsev, A.N.; Couëslan, C.; Xu, C.; Kynický, J.; Mumin, A.H.; Yang, P. Apatite in carbonatitic rocks: Compositional variation, zoning, element partitioning and petrogenetic significance. Lithos 2017, 274-275, 188-213. [CrossRef]

83. Taylor, H.P.; Frechen, J.; Degens, E.T. Oxygen and carbon isotope studies of carbonatites from the Laacher See District, West Germany and the Alnö District, Sweden. Geochim. Cosmochim. Acta 1967, 31, 407-430. [CrossRef]

84. Sheppard, S.M.F.; Dawson, J.B. C13/C12 and D/H isotope variations in "Primary Igneous Carbonatites". Fortschr. Miner. 1973, $50,128-129$.

85. Hoefs, J. Stable Isotope Geochemistry, 3rd ed.; Springer: Berlin/Heidelberg, Germany, 1987.

86. Keller, J.; Hoefs, J. Stable Isotope Characteristics of Recent Natrocarbonatites from Oldoinyo Lengai. In Carbonatite Volcanism: Oldoinyo Lengai and the Petrogenesis of Natrocarbonatites; Bell, K., Keller, J., Eds.; Springer-Verlag: Berlin/Heidelberg, Germany, 1995; pp. 113-123.

87. Mikhail, S.; Shahar, A.; Hunt, S.A.; Verchovsky, A.B.; Jones, A.P. An experimental investigation of the pressure effect on stable isotope fractionation at high temperature: Implications for mantle processes and core formation in celestial bodies. In Proceedings of the Lunar and Planetary Science Conference, The Woodlands, TX, USA, 7-11 March 2011.

88. Marty, B.; Alexander, C.M.O.D.; Raymond, S.N. Primordial origins of earth's carbon. Rev. Mineral. Geochemistry 2013, 75, 149-181. [CrossRef]

89. Shirey, S.B.; Cartigny, P.; Frost, D.J.; Keshav, S.; Nestola, F.; Nimis, P.; Pearson, D.G.; Sobolev, N.V.; Walter, M.J. Diamonds and the geology of mantle carbon. Rev. Mineral. Geochemistry 2013, 75, 355-421. [CrossRef]

90. Wood, B.J.; Li, J.; Shahar, A. Carbon in the core: Its influence on the properties of core and mantle. Rev. Mineral. Geochem. 2013, 75, 231-250. [CrossRef]

91. Deines, P. Stable isotope variations in carbonatites. In Genesis and Evolution; Bell, K., Ed.; Unwin Hyman Ltd.: London, UK, 1989; pp. 301-359.

92. Santos, R.V.; Clayton, R.N. Variations of oxygen and carbon isotopes in carbonatites: A study of Brazilian alkaline complexes. Geochim. Cosmochim. Acta 1995, 59, 1339-1352. [CrossRef]

93. Hart, S.R.; Hauri, E.H.; Oschmann, L.A.; Whitehead, J.A. Mantle plumes and entrainment: Isotopic evidence. Science 1992, 256, 517-520. [CrossRef] [PubMed]

94. Hauri, E.H.; Whitehead, J.A.; Hart, S.R. Fluid dynamic and geochemical aspects of entrainment in mantle plumes. J. Geophys. Res. 1994, 99, 24275-24300. [CrossRef]

95. Stracke, A.; Hofmann, A.W.; Hart, S.R. FOZO, HIMU, and the rest of the mantle zoo. Geochem. Geophys. Geosyst. 2005, 6, 1-20. [CrossRef]

96. Jackson, M.G.; Kurz, M.D.; Hart, S.R.; Workman, R.K. New Samoan lavas from Ofu Island reveal a hemispherically heterogeneous high 3He/4He mantle. Earth Planet. Sci. Lett. 2007, 264, 360-374. [CrossRef] 
97. Millet, M.A.; Doucelance, R.; Schiano, P.; David, K.; Bosq, C. Mantle plume heterogeneity versus shallow-level interactions: A case study, the São Nicolau Island, Cape Verde archipelago. J. Volcanol. Geotherm. Res. 2008, 176, 265-276. [CrossRef]

98. Hart, S.R. Heterogeneous mantle domains: Signatures, genesis and mixing chronologies. Earth Planet. Sci. Lett. 1988, 90, 273-296. [CrossRef]

99. Gurenko, A.A.; Hoernle, K.A.; Hauff, F.; Schmincke, H.U.; Han, D.; Miura, Y.N.; Kaneoka, I. Major, trace element and Nd-Sr-Pb-OHe-Ar isotope signatures of shield stage lavas from the central and western Canary Islands: Insights into mantle and crustal processes. Chem. Geol. 2006, 233, 75-112. [CrossRef]

100. Doucelance, R.; Escrig, S.; Moreira, M.; Gariépy, C.; Kurz, M.D. Pb-Sr-He isotope and trace element geochemistry of the Cape Verde Archipelago. Geochim. Cosmochim. Acta 2003, 67, 3717-3733. [CrossRef]

101. Abouchami, W.; Galer, S.J.G.; Hofmann, A.W. High precision lead isotope systematics of lavas from the Hawaiian Scientific Drilling Project. Chem. Geol. 2000, 169, 187-209. [CrossRef]

102. Bryce, J.G.; DePaolo, D.J.; Lassiter, J.C. Geochemical structure of the Hawaiian plume: Sr, Nd, and Os isotopes in the $2.8 \mathrm{~km}$ HSDP-2 section of Mauna Kea volcano. Geochem. Geophys. Geosyst. 2005, 6, 1-36. [CrossRef]

103. Harrison, L.N.; Weis, D. The Size and Emergence of Geochemical Heterogeneities in the Hawaiian Mantle Plume Constrained by Sr-Nd-Hf Isotopic Variation Over 47 Million Years. Geochem. Geophys. Geosyst. 2018, 19, 2823-2842. [CrossRef]

104. Gerlach, D.C.; Cliff, R.A.; Davies, G.R.; Norry, M.; Hodgson, N. Magma sources of the Cape Verdes archipelago: Isotopic and trace element constraints. Geochim. Cosmochim. Acta 1988, 52, 2979-2992. [CrossRef]

105. Bonadiman, C.; Beccaluva, L.; Coltorti, M.; Siena, F. Kimberlite-like metasomatism and "garnet signature" in spinel-peridotite xenoliths from Sal, Cape Verde Archipelago: Relics of a subcontinental mantle domain within the Atlantic oceanic lithosphere? J. Petrol. 2005, 46, 2465-2493. [CrossRef]

106. Martins, S.; Mata, J.; Munhá, J.; Mendes, M.H.; Maerschalk, C.; Caldeira, R.; Mattielli, N. Chemical and mineralogical evidence of the occurrence of mantle metasomatism by carbonate-rich melts in an oceanic environment (Santiago Island, Cape Verde). Mineral. Petrol 2010, 99, 43-65. [CrossRef]

107. Allègre, C.J.; Moreira, M.; Staudacher, T. $4 \mathrm{He} /{ }^{3} \mathrm{He}$ dispersion and mantle convection. Geophys. Res. Lett. 1995, 22, $2325-2328$. [CrossRef]

108. Gautheron, C.; Moreira, M. Helium signature of the subcontinental lithospheric mantle. Earth Planet. Sci. Lett. 2002, 199, 39-47. [CrossRef]

109. Broadley, M.W.; Barry, P.H.; Bekaert, D.V.; Byrne, D.J.; Caracausi, A.; Ballentine, C.J.; Marty, B. Identification of chondritic krypton and xenon in Yellowstone gases and the timing of terrestrial volatile accretion. Proc. Natl. Acad. Sci. USA 2020, 117, 13997-14004 [CrossRef] [PubMed]

110. Day, J.M.D.; Hilton, D.R. Heterogeneous mantle-derived helium isotopes in the Canary Islands and other ocean islands. Geology 2020, 49. [CrossRef]

111. Day, J.M.D.; Hilton, D.R. Origin of 3He/4He ratios in HIMU-type basalts constrained from Canary Island lavas. Earth Planet. Sci. Lett. 2011, 305, 226-234. [CrossRef]

112. Hoernle, K.; Tilton, G.; Schmincke, H.U. Sr-Nd-Pb isotopic evolution of Gran Canaria: Evidence for shallow enriched mantle beneath the Canary Islands. Earth Planet. Sci. Lett. 1991, 106, 44-63. [CrossRef]

113. Gurenko, A.A.; Hoernle, K.A.; Sobolev, A.V.; Hauff, F.; Schmincke, H.U. Source components of the Gran Canaria (Canary Islands) shield stage magmas: Evidence from olivine composition and Sr-Nd-Pb isotopes. Contrib. Mineral. Petrol. 2010, 159, 689-702. [CrossRef]

114. Grachev, A.F. MORB-like mantle beneath Lanzarote Island, Canary Islands. Russ. J. Earth Sci. 2012, 12, 1-7. [CrossRef]

115. Christensen, B.P.; Holm, P.M.; Jambon, A.; Wilson, J.R. Helium, argon and lead isotopic composition of volcanics from Santo Antão and Fogo, Cape Verde Islands. Chem. Geol. 2001, 178, 127-142. [CrossRef] 